\title{
Numerical Simulation of Groundwater Withdrawal from Proposed Pumping Near the Southeastern Nevada Test Site
}

\author{
Prepared by \\ Rosemary W.H. Carroll, Ronald L. Hershey and Greg M. Pohll \\ submitted to \\ Nevada Site Office \\ National Nuclear Security Administration \\ U.S. Department of Energy \\ Las Vegas, Nevada
}

April 2006

Publication No. 45217 
Reference herein to any specific commercial product, process, or service by trade name, trademark, manufacturer, or otherwise, does not necessarily constitute or imply its endorsement, recommendation, or favoring by the United States Government or any agency thereof or its contractors or subcontractors.

Available for sale to the public from:

U.S. Department of Commerce

National Technical Information Service

5285 Port Royal Road S/D

Springfield, VA 22161-0002

Phone: 800.553.6847

Fax: 703.605.6900

Email: orders@ntis.gov

Online ordering: http://www.osti.gov/ordering.htm

Available electronically at http://www.osti.gov/bridge

Available for a processing fee to the U.S. Department of Energy and its contractors, in paper, from:

U.S. Department of Energy

Office of Scientific and Technical Information

P.O. Box 62

Oak Ridge, TN 37831-0062

Phone: 865.576 .8401

Fax: 865.576.5728

Email: reports@adonis.osti.gov 


\title{
Numerical Simulation of Groundwater Withdrawal from Proposed Pumping Near the Southeastern Nevada Test Site
}

\author{
Prepared by \\ Rosemary W.H. Carroll, Ronald L. Hershey and Greg M. Pohll \\ Division of Hydrologic Sciences \\ Desert Research Institute \\ Nevada Division of Higher Education
}

Publication No. 45217

\author{
Submitted to \\ Nevada Site Office \\ National Nuclear Security Administration \\ U.S. Department of Energy \\ Las Vegas, Nevada
}

April 2006

The work upon which this report is based was supported by the U.S. Department of Energy under Contract \#DE-AC52-00NV13609. Approved for public release; further dissemination unlimited. 
THIS PAGE INTENTIONALLY LEFT BLANK 


\begin{abstract}
Current modeling of the southeastern portion of the Nevada Test Site (NTS) with a refined U.S. Geological Survey Death Valley regional groundwater flow system model shows that impacts from pumping by proposed Southern Nevada Water Authority (SNWA) and Vidler Water Company (VWC) wells can be substantial over 75 years of operation. Results suggest that significant drawdown at proposed well sites will occur with depths of drawdown ranging from $8 \mathrm{~m}$ to nearly $1,600 \mathrm{~m}$. The areal extent of $0.5 \mathrm{~m}$ of drawdown is also significant, impacting Mercury Valley, Amargosa, Indian Springs, Three Lakes, and Frenchman Flat basins. Drawdown will impact Army \#1 Water Well in Mercury Valley by lowering water levels $2.1 \mathrm{~m}$ but will not impact other NTS production wells. It is also predicted that flowpaths from detonation sites within the NTS will be altered with the potential to move material out of the NTS. Impacts to both springs and regions of groundwater evapotranspiration (modeled as MODFLOW drain cells) appear very minimal, with an estimated 0.2-percent reduction in flow to these regions. This amounts to a loss of more that $55,000 \mathrm{~m}^{3} /$ year (45 acre- $\mathrm{ft} /$ year), or more than 4,000,000 $\mathrm{m}^{3}$ (3,400 acre- $\mathrm{ft}$ ) during 75 years of groundwater withdrawal by pumping at proposed SNWA and VWC wells. Whether the reduced flow will impact specific springs more than any others, or if the reduction in flow is enough to have significant ecological implications, was not addressed in this study.
\end{abstract}


THIS PAGE INTENTIONALLY LEFT BLANK 


\section{CONTENTS}

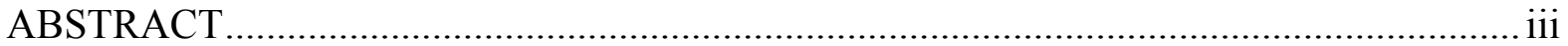

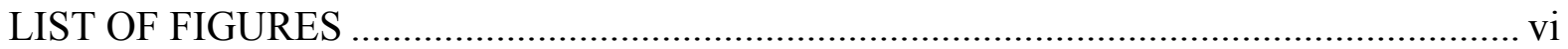

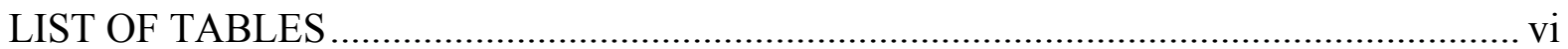

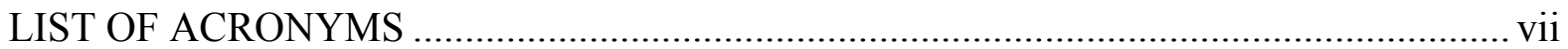

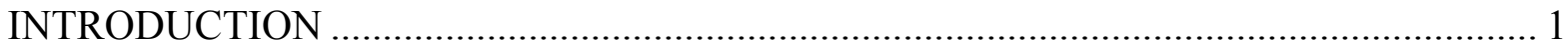

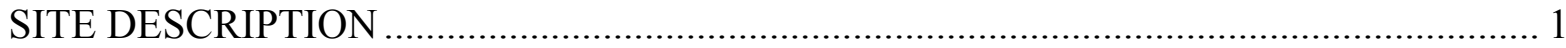

Death Valley Regional Groundwater Flow System Model - Previous Work ...................... 2

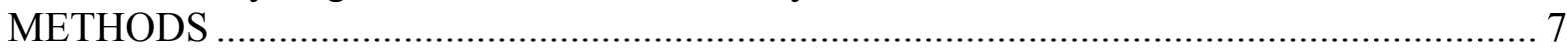

Refined Grid and Reduced Model Domain ..................................................................... 7

Refined Grid Properties/Modification to MODFLOW-2000 Input Files .............................. 9

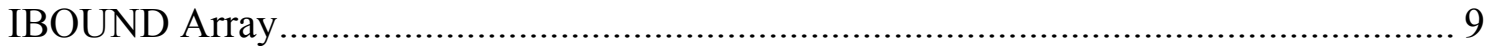

Starting Heads and Layer Elevations ....................................................................... 9

Constant Head Boundary ...................................................................................... 10

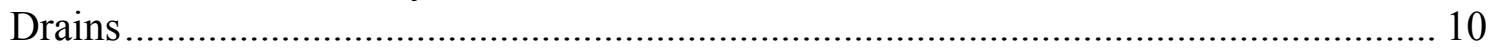

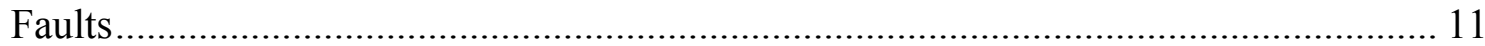

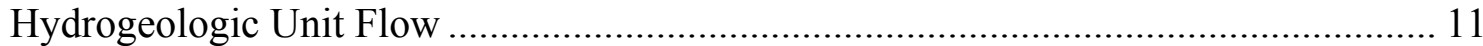

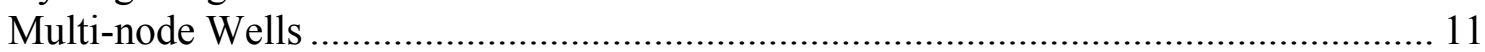

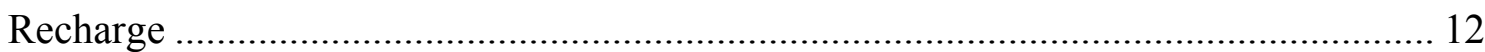

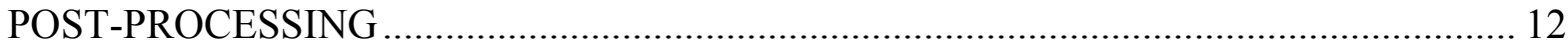

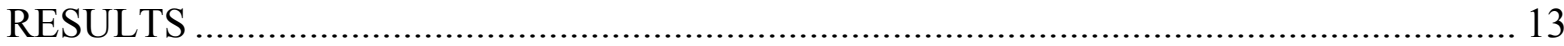

Comparison between Original and Refined Models ......................................................... 13

Effects of Additional Pumping …………………….................................................... 13

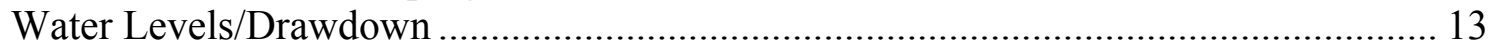

Water Levels/Drawdown ................................................................................. 15

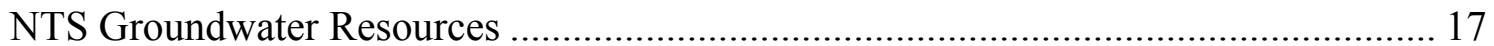

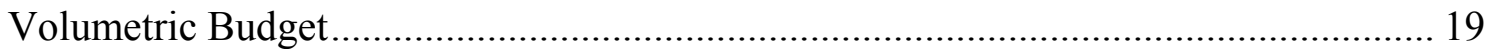

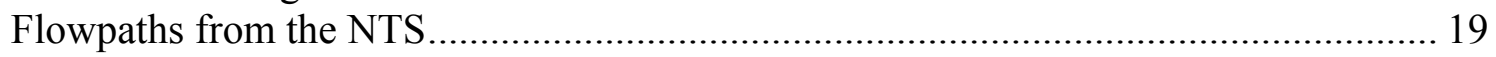

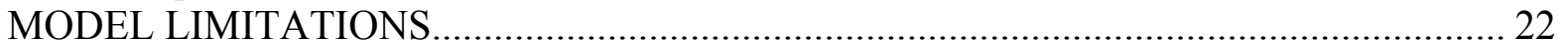

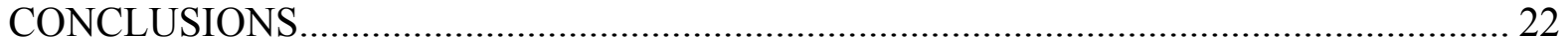

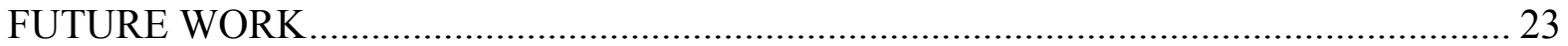

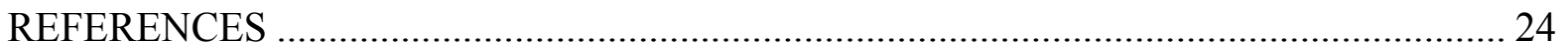




\section{LIST OF FIGURES}

1. Location of the Death Valley groundwater flow system (and associated model boundary) with proposed pumping well locations marked. ................................................................ 2

2. Cell structure in the DVRFSM. ............................................................................... 4

3. An example of designated boundary conditions and cell stresses within the DVRFSM......... 5

4. Location of recharge zones in the DVRFSM. Zones are defined in Table 2 ......................... 6

5. DVRFSM simulated heads for current pumping conditions (year 1998)............................. 7

6. Location of new model domain in relation to the larger DVRFSM. ................................... 8

7. Designation of original cell properties (M-1 and M-2) to refined cells when refined cells are (a) a multiple of the original cell size, and (b) not a multiple of the original cell size...... 9

8. An example of assigning a starting head from the original grid to the refined grid.............. 10

9. Example of assigning constant head cells from the original grid to the refined grid. ........... 10

10. Example of assigning horizontal flow barrier (HFB) cells from the original grid to the

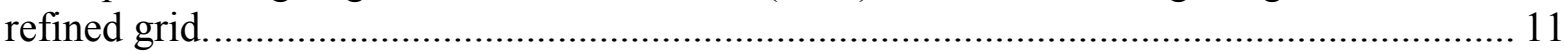

11. Visual comparison of top layer final heads for 1998 pumping conditions between (a) original DVRFSM and (b) refined model................................................................... 14

12. Spatially distributed error $(\mathrm{m})$ computed as refined grid head minus DVRFSM head. ......... 15

13. The areal extent of the $0.5-\mathrm{m}$ contour (gray shaded region) for excess drawdown from additional VWC and SNWA pumping wells for (a) the top layer and (b) the bottom layer. . 16

14. Excess drawdown over time at pumping well locations (a) SNWA and (b) VWC. Well

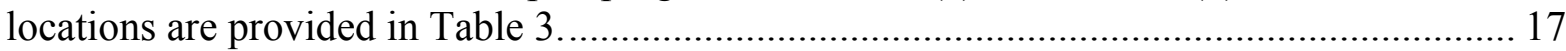

15. Locations of operating NTS pumping wells in relation to areal extent of excess drawdown in layer 1

16. The relative amount of drawdown in proposed pumping wells after 75 years of pumping compared to steady-state drawdown values.

17. Comparison of steady-state pathlines from three NTS detonation sites superimposed on a map of excess drawdown.

\section{LIST OF TABLES}

1. Thickness and depth to the top of each layer of the DVRFSM ....................................... 4

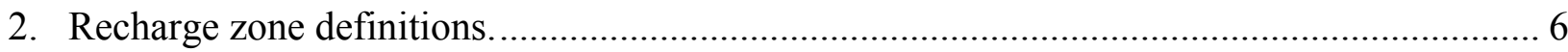

3. Locations and pumping rates of SNWA and VWC proposed wells................................. 12

4. Excess drawdown at NTS water-supply wells caused by additional pumping at proposed SNWA and VWC wells.

5. A comparison of cumulative volumetric budget for the 75-year forward scenario given no additional pumping and additional pumping wells. 


\section{LIST OF ACRONYMS}

$\begin{array}{ll}\text { DOE } & \text { U.S. Department of Energy } \\ \text { DVRFS } & \text { Death Valley Regional Groundwater Flow System } \\ \text { DVRFSM } & \text { Death Valley Regional Groundwater Flow System Model } \\ \text { HRMP } & \text { Hydrologic Resources Management Program } \\ \text { NNSA/NSO } & \text { National Nuclear Security Administration/Nevada Site Office } \\ \text { NTS } & \text { Nevada Test Site } \\ \text { OCRWM } & \text { Office of Civilian Radioactive Waste Management } \\ \text { SNWA } & \text { Southern Nevada Water Authority } \\ \text { UGTA } & \text { Underground Test Area } \\ \text { USGS } & \text { United States Geological Survey } \\ \text { VWC } & \text { Vidler Water Company } \\ \text { YMP } & \text { Yucca Mountain Project }\end{array}$


THIS PAGE INTENTIONALLY LEFT BLANK 


\section{INTRODUCTION}

There have been numerous water rights applications submitted throughout southern Nevada to accommodate growth in Las Vegas. Several applications include groundwater withdrawals adjacent to the Nevada Test Site (NTS). If large quantities of groundwater are pumped adjacent to the NTS, the groundwater system could change dramatically. Potential impacts from groundwater pumping include (1) decreasing water levels, (2) reduction in groundwater resources on the NTS, (3) reduction in spring flows adjacent to proposed pumping centers, and (4) the alteration of groundwater flowpaths. The objective of this study is to investigate the potential impacts from proposed pumping near the southeastern portion of the NTS.

To identify these potential impacts, the U.S. Geological Survey (USGS) Death Valley

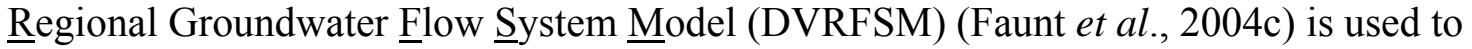
create a refined groundwater model for the region associated with proposed pumping. Hydrogeologic data are extracted from the DVRFSM for the region of interest to populate the local-scale model. This is done because the DVRFSM has a grid spacing of 1,500 $\mathrm{m}$ in the horizontal direction, which is too large to adequately simulate the groundwater system over a smaller region. The refined model represents a balance between being large enough to incorporate adjacent pumping areas and keeping simulated withdrawals independent of boundary conditions.

There are three parties who have applied for water rights near the NTS. These parties include the Vidler Water Company (VWC), the Southern Nevada Water Authority (SNWA), and the Las Vegas Valley Water District. The groundwater modeling effort presented in this study focuses on the VWC and SNWA applications located in two State of Nevada administrative groundwater basins near the southeastern edge of the NTS, because these basins have the highest potential to adversely impact the NTS groundwater system in the near term. Seven wells are proposed for each of the two companies for a total of 14 additional pumping wells. Southern Nevada Water Authority is applying for $14,680 \mathrm{~m}^{3} /$ day $(11.9$ acre$\mathrm{ft} /$ day) for each well, or a total of $37,506,123 \mathrm{~m}^{3} /$ year $(30,429$ acre-ft/year) from its seven wells. Vidler Water Company is proposing $4,159 \mathrm{~m}^{3} /$ day (3.4 acre-ft/day) for each well, or a total of $10,626,756 \mathrm{~m}^{3} /$ year $(8,624 \mathrm{acre}-\mathrm{ft} /$ year $)$ from its seven wells. Impacts are assessed after 75 years of pumping, after which it is assumed a county can assert a quantifiable need for the water to the state engineer and re-acquire the water rights.

\section{SITE DESCRIPTION}

The DVRFS is shown in Figure 1. It encompasses approximately $100,000 \mathrm{~km}^{2}$ in Nevada and California and is bounded by latitudes $35^{\circ} 00^{\prime} \mathrm{N}$ and $38^{\circ} 15^{\prime} \mathrm{N}$ and by longitudes $115^{\circ} 00^{\prime} \mathrm{W}$ and $118^{\circ} 00^{\prime} \mathrm{W}$. Also shown in Figure 1 are the NTS and proposed VWC and SNWA pumping wells.

The DVRFS encompasses flow between recharge areas in the mountains of central and southern Nevada and discharge areas of wet playas and springs south and west of the NTS and in Death Valley, California. The flow is strongly influenced by a complex geologic framework and any robust model must incorporate the three-dimensional distribution of its 
principal aquifers and confining units as well as the principal geologic structures that might affect subsurface flow.

\section{Death Valley Regional Groundwater Flow System Model - Previous Work}

In 1998, the U.S. Department of Energy (DOE) Nevada Site Office funded the USGS for five years to improve upon the two previous groundwater flow models of the Death Valley region. The first of these earlier models was developed by DOE for the National Nuclear Security Administration/Nevada Site Office (NNSA/NSO) Underground Test Area (UGTA) project and is referred to as the DOE/NSO-UGTA model (IT Corporation, 1996).

The second of these earlier models was developed by the Office of Civilian Radioactive Waste Management's (OCRWM) Yucca Mountain Project (YMP) and the NNSA/NSO Hydrologic Resources Management Program (HRMP) called the YMP/HRMP model.

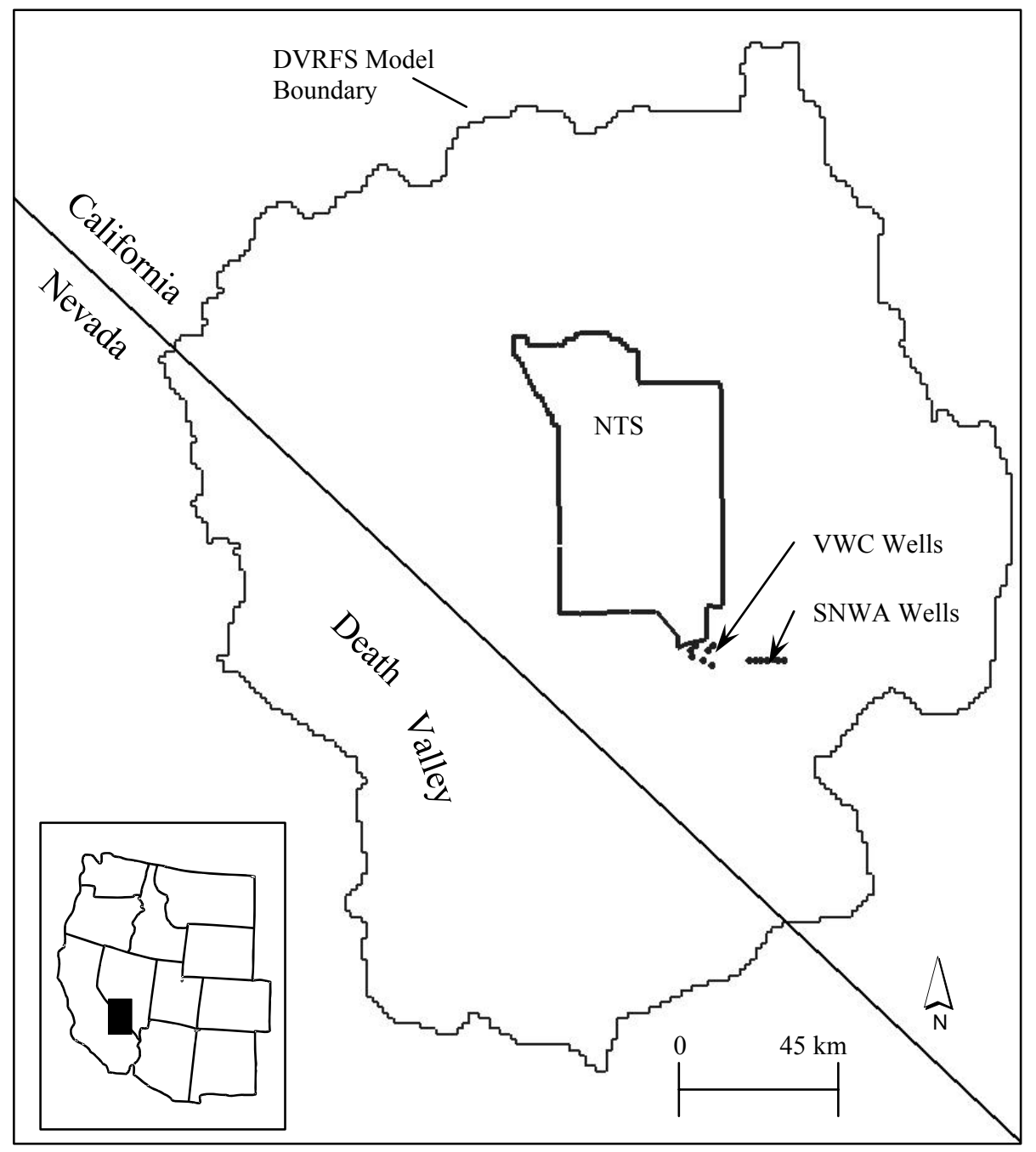

Figure 1. Location of the Death Valley groundwater flow system (and associated model boundary) with proposed pumping well locations marked. 
(D'Agnese et al., 1997). While both of these models are based on similar hydrologic data sets, they differ in their interpretation of the hydrogeology at the regional scale. The USGS DVRFSM has improved upon these earlier modeling approaches using newly acquired data and modeling tools. The initial intention of the DVRFSM was to understand groundwater flowpaths and travel times associated with potential movement of radioactive material from the NTS, characterize the groundwater system in the vicinity of Yucca Mountain, and address effects on users downgradient from the NTS and Yucca Mountain (Belcher et al., 2004). To build and calibrate the transient DVRFSM, several studies were conducted including: reassessing groundwater discharge via evapotranspiration (ET) and spring flow, cataloging historical groundwater pumping from 1913 through 1998, reinterpreting groundwater recharge as net infiltration, assessing model boundary inflows and outflows from regional hydraulic gradients, developing a water budget, and incorporating hydraulic conductivity relationships as a function of depth (Sweetkind et al., 2004; San Juan et al., 2004; Faunt et al., 2004a, b, c).

With increased data, better interpretation tools, advances in computing power and in modeling routines, the DVRFSM hydrogeologic framework represents an increased level of geologic detail and better model calibration than previous studies. The final result is a calibrated transient numerical groundwater flow model that simulates conditions from 1913 through 1998 using the modular, finite-difference groundwater flow model MODFLOW2000 (Harbaugh et al., 2000). A complete description of the construction, calibration, and uncertainties of the transient flow model is provided by Faunt et al. (2004c).

In brief, the DVRFSM comprises constant-grid spacing in the horizontal plane at $1,500 \mathrm{~m}$ by $1,500 \mathrm{~m}$. The grid is oriented north-south, with 160 columns, 194 rows, and 16 layers, for a total of 496,640 cells. Figure 2 shows the cell structure of the DVRFSM to provide a sense of scale of cell size and orientation with respect to the model domain. Cell thicknesses range between $50 \mathrm{~m}$ to more than $3,000 \mathrm{~m}$, with layer 16 (the bottom layer) reaching $4,000 \mathrm{~m}$ below sea level. Thickness and depths to the top of each layer are given in Table 1 . The upper layers represent relatively shallow basin-fill sediments and volcanics, while deeper layers represent the regional carbonate aquifer. Twenty-seven hydrogeologic units are defined in the DVRFSM via the MODFLOW-2000 Hydrogeologic Unit Flow-2 (HUF2) package (Anderman and Hill, 2000, 2003). Calibration procedures refined these units based upon hydraulic conductivity, vertical anisotropy, and storage parameters. Model cells containing more than one hydrogeologic unit are simulated with vertically averaged hydraulic properties. For a full description of the DVRFSM hydrogeologic framework and its associated HUF2 package, refer to Faunt et al. (2004b, c).

Model calibration was accomplished by best matching 4,899 observations of hydraulic head and 49 observations of groundwater discharge with MODFLOW-2000 parameter estimation processes (Hill et al., 2000). One hundred parameters were estimated in the calibration process including hydraulic conductivity, vertical anisotropy, drain conductance, fault-associated hydraulic conductivity, recharge zone multipliers, depth decay coefficients for hydraulic conductivity, and storage parameters (storativity and specific yield). Figure 3 provides an example of where boundary conditions, applied stresses (e.g., wells, drains), and faults are designated in the DVRFSM top layer during the final timestep 


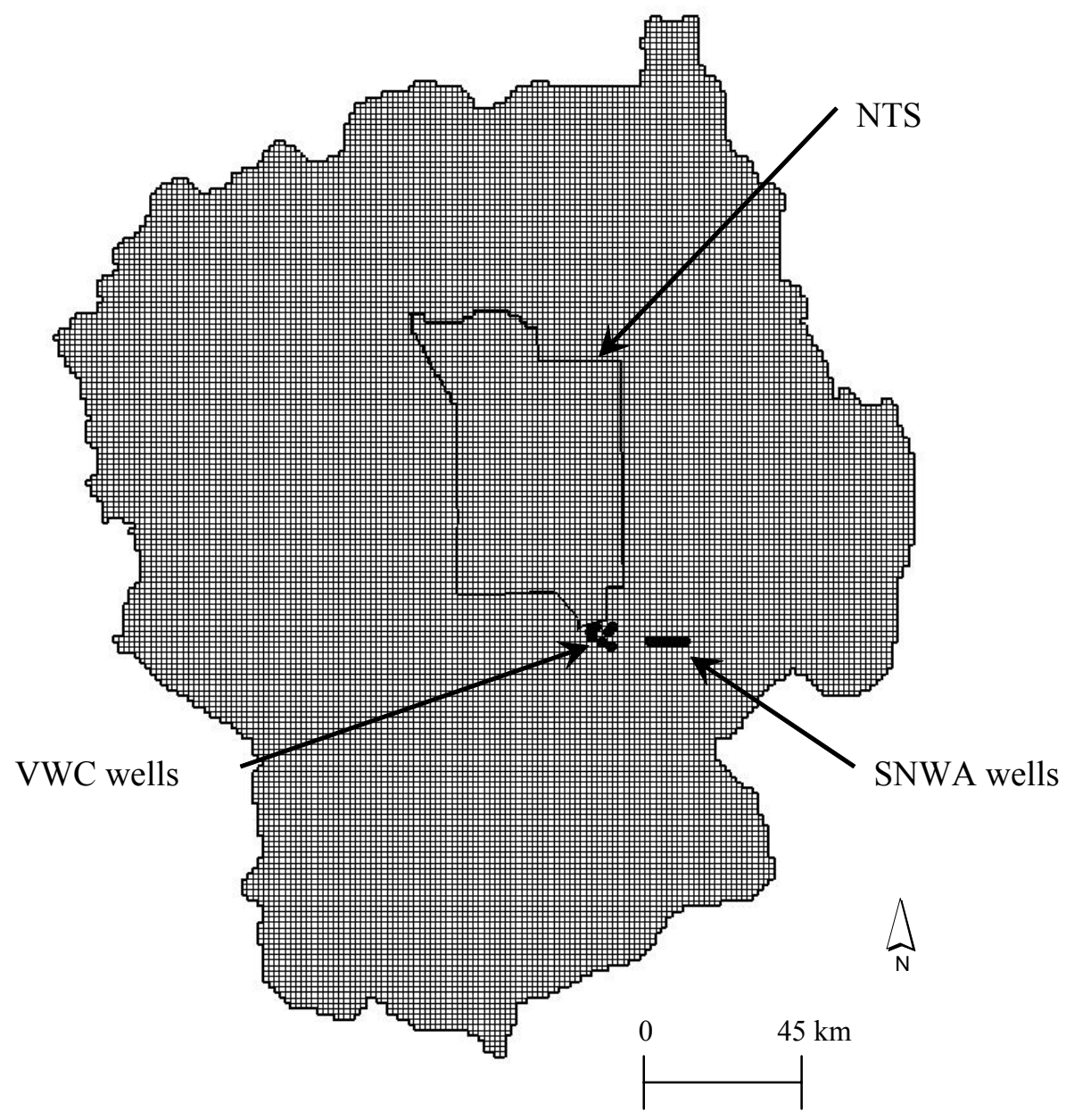

Figure 2. Cell structure in the DVRFSM.

Table 1. Thickness and depth to the top of each layer of the DVRFSM (taken directly from Faunt et al., 2004c)

\begin{tabular}{ccc}
\hline Model Layer & Layer Thickness $(\mathbf{m})$ & Min Depth to Top of Layer $(\mathbf{m})$ \\
\hline 1 & 1 to 850 & NA \\
2 & 50 & 50 \\
3 & 50 & 100 \\
4 & 100 & 150 \\
5 & 100 & 250 \\
6 & 100 & 350 \\
7 & 100 & 450 \\
8 & 100 & 550 \\
9 & 100 & 650 \\
10 & 100 & 750 \\
11 & 150 & 850 \\
12 & 200 & 1,000 \\
13 & 250 & 1,200 \\
14 & 250 & 1,450 \\
15 & 300 & 1,700 \\
16 & 1,800 to 5,000 & 2,000 \\
\hline
\end{tabular}


(year 1998). Lateral flows across the model boundary are specified as constant head cells that were interpolated from the regional potentiometric surface. The southeastern edge near the Spring Mountains, however, contains a no-flow boundary. Drains were used to define both groundwater ET and spring flows where discharge was defined by observation but conductances were estimated by parameter estimation. Faults acting as barriers to flow were defined in MODFLOW-2000 with the Horizontal-flow Barrier (HFB) package. Faults were assumed to extend the entire thickness of the model and the width of each fault was assumed $1 \mathrm{~m}$, while the hydraulic conductivity of each fault was determined by parameter estimation. Nine faults were found to exert some influence on hydraulic heads and are shown in Figure 2. Recharge flux was applied to the uppermost active cells in one of nine zones displayed in Figure 4 and defined in Table 2. Recharge in each zone was calibrated via a multiplier value also given in Table 2.

The U.S. Geological Survey evaluated the model in terms of the regional water budget, model fit, and values of parameter estimates and their associated sensitivities (Faunt et al., 2004c). Resulting simulated heads for current pumping conditions (i.e., final timestep, or year 1998) are shown in Figure 5.

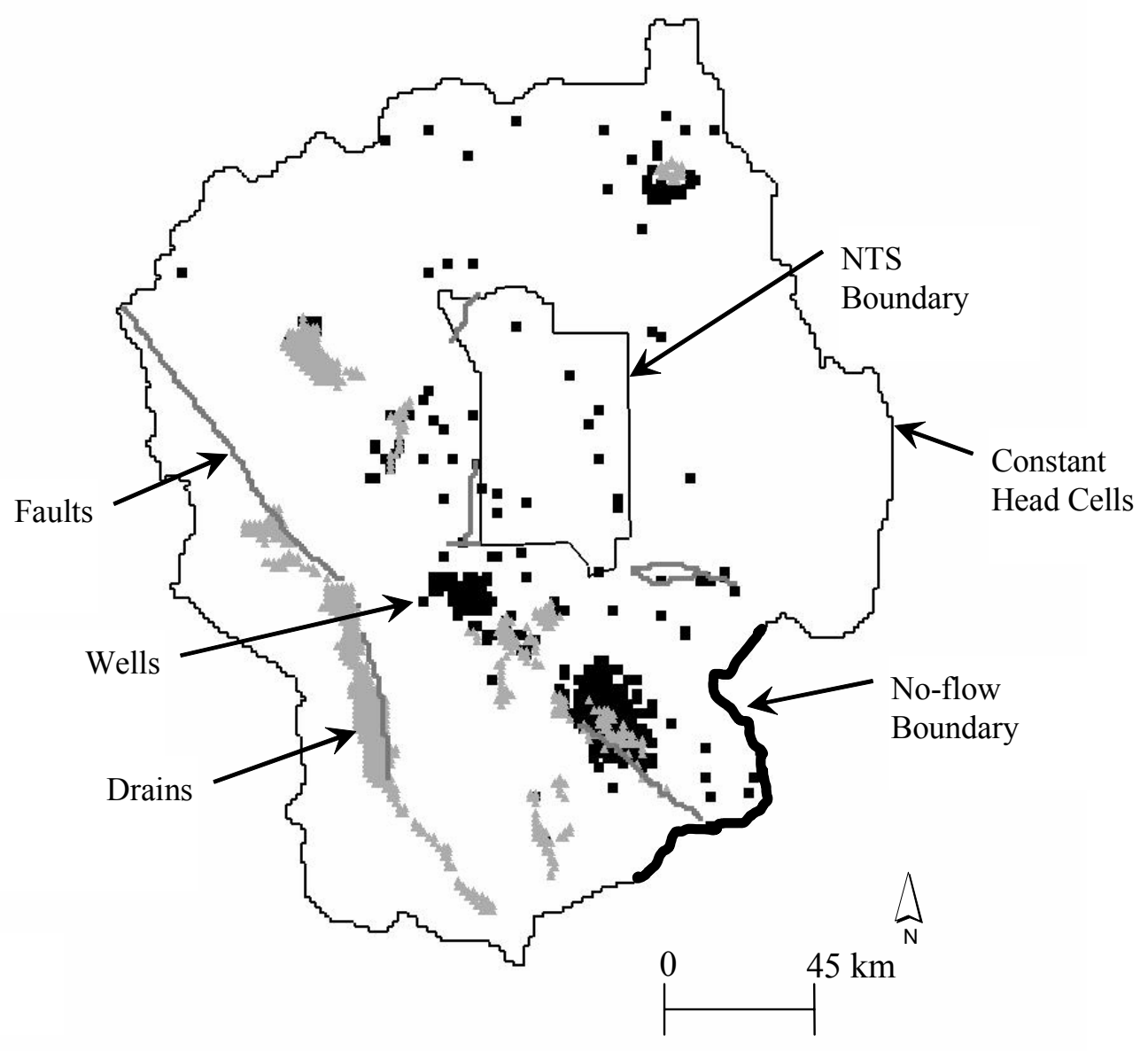

Figure 3. An example of designated boundary conditions and cell stresses within the DVRFSM (year 1998, top layer). 


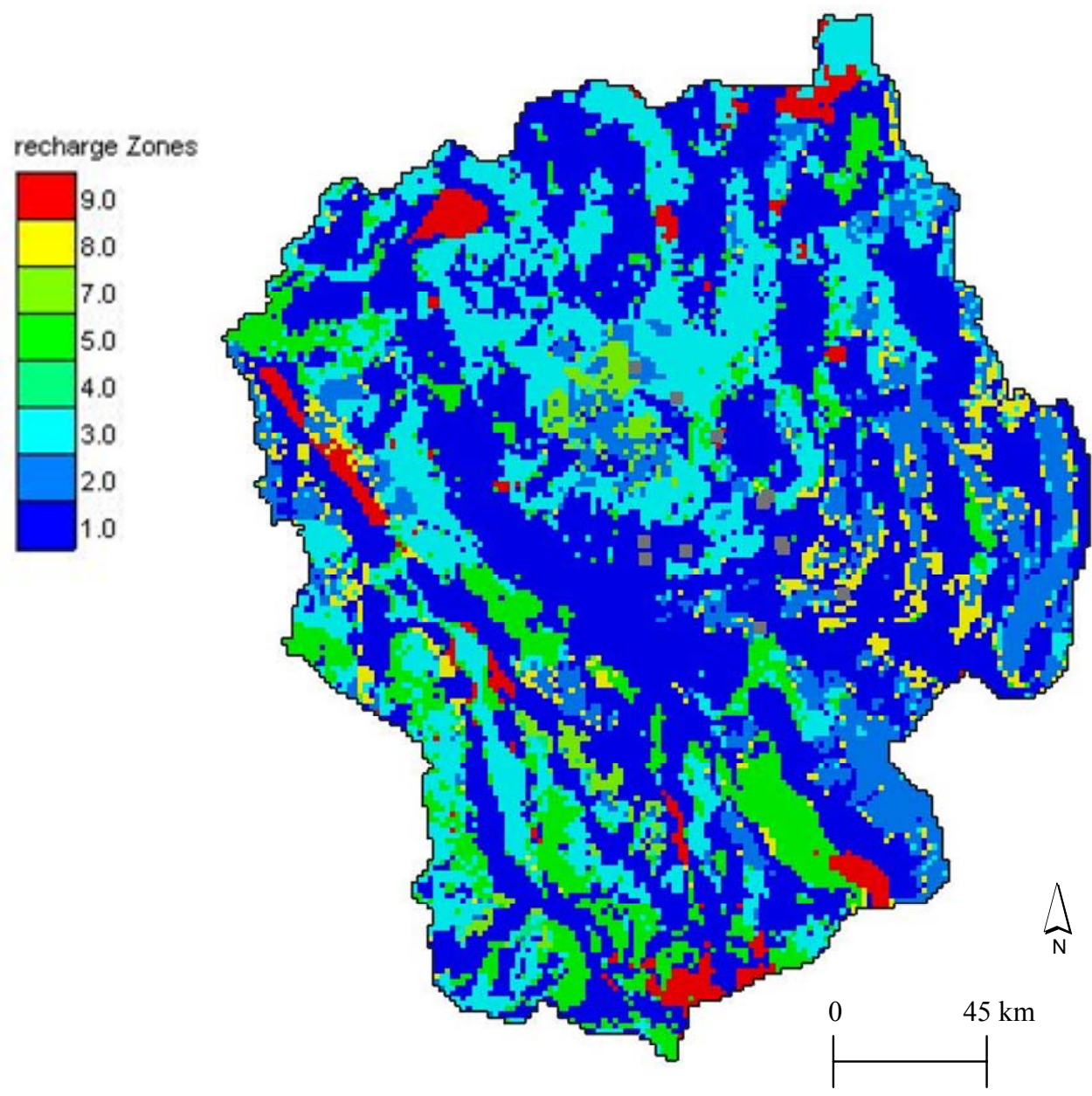

Figure 4. Location of recharge zones in the DVRFSM. Zones are defined in Table 2.

Table 2. Recharge zone definitions.

\begin{tabular}{ccclc}
\hline Zone & $\begin{array}{c}\text { Relative } \\
\text { Permeability }\end{array}$ & $\begin{array}{c}\text { Relative } \\
\text { Infiltration Rate }\end{array}$ & $\begin{array}{c}\text { Description } \\
\text { Multiplier }\end{array}$ \\
\hline 1 & NA & None & No infiltration & NA \\
2 & High & High & Generally, carbonate rocks in the Spring Mtns. & 0.76 \\
& & and southern part of the Sheep Range & \\
3 & Low & High to Moderate & Generally, volcanic and/or clastic rocks & 1.12 \\
4 & High & Moderate to Low & Various rock types & 1 \\
5 & Low & Low & Generally, volcanic and/or clastic rocks & 1.12 \\
6 & High & Moderate to Low & Basin-fill aquifers present in upper 5 layers & 1 \\
7 & High & Moderate to Low & Volcanic rocks present in upper 5 layers & 1 \\
8 & High & Moderate to Low & Carbonate rocks present in upper 5 layers & 1 \\
9 & NA & NA & Cells where recharge exceeded hydraulic & 0.000001 \\
\hline
\end{tabular}




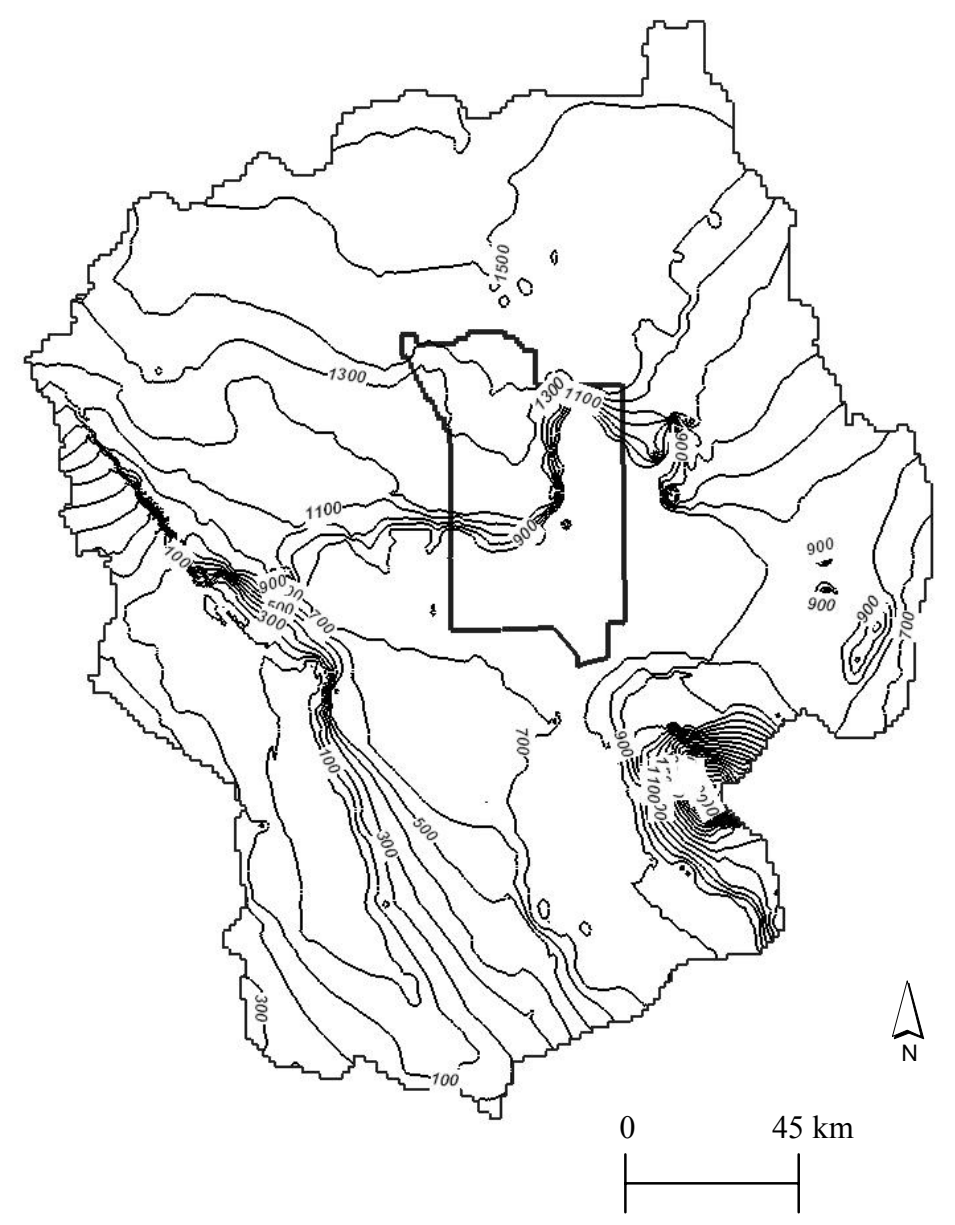

Figure 5. DVRFSM simulated heads for current pumping conditions (year 1998). Contour interval is $100 \mathrm{~m}$, NTS shown for reference.

\section{METHODS}

The DVRFSM is currently the best numerical tool for study of the DVRFS. However, the cell dimension of $1,500 \mathrm{~m}$ by $1,500 \mathrm{~m}$ in the horizontal direction is too coarse to address the impacts of pumping wells in a much smaller geographic area than the entire DVRFS, necessitating a finer grid resolution. The refined model domain was likewise reduced. It is only necessary to keep the model domain large enough to incorporate adjacent pumping areas and keep simulated withdrawals independent of boundary conditions.

\section{Refined Grid and Reduced Model Domain}

Several criteria were used to establish the size of the model domain. First, it was necessary to select boundaries that encompassed the impacted region and were far enough away from the pumping wells to remove any boundary affects on predicted drawdown. It was also necessary to include one or more detonation sites within the NTS to look at possible alterations to contaminant pathlines from these locations. The new domain's northwest and southeast corners are located on the original grid's row/column at 78/60 and 151/136, respectively. 
A refined cell size that is a multiple of $1,500 \mathrm{~m}$ (e.g., $500 \mathrm{~m}, 300 \mathrm{~m}, 100 \mathrm{~m}$, etc.) makes the assignment of physical and hydraulic properties easier on a cell-by-cell basis. Otherwise, averaging calculations complicate the translation from one grid to another and can potentially introduce error. As an example, Figure 7a shows that a refined cell size of one-third the original cell size (X) allows easy designation of material 1 (M-1) or material 2 (M-2) properties from the original cell to the refined cell. On the other hand, assigning properties from material 1 and material 2 in Figure $7 \mathrm{~b}$ is more complicated when the refined cell size is three-sevenths the original cell size because of cell overlap. A cell size of $500 \mathrm{~m} \mathrm{x}$ $500 \mathrm{~m}$ in the horizontal plane was chosen such that nine refined cells fit evenly within a single original cell. No alteration was made to cells in the vertical dimension. The final grid contains 231 columns, 222 rows, and 16 layers, for a total of 820,512 cells, or 40 percent more cells than the original DVRFSM, and a computation time of less than 10 minutes on a fast computer (Intel Pentium 4 CPU $3.80 \mathrm{GHz}, 0.99 \mathrm{~GB}$ of RAM).

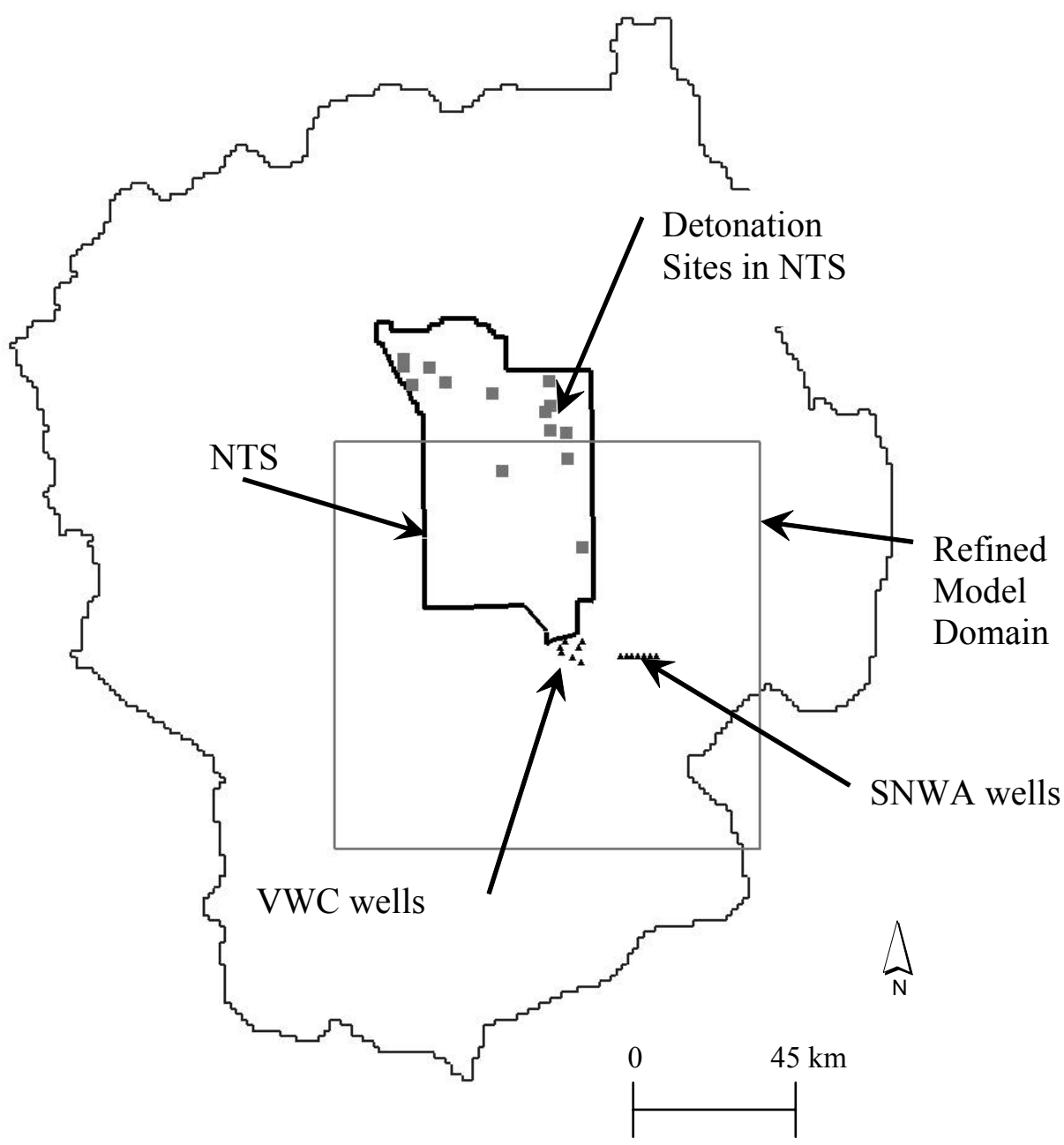

Figure 6. Location of new model domain in relation to the larger DVRFSM. 


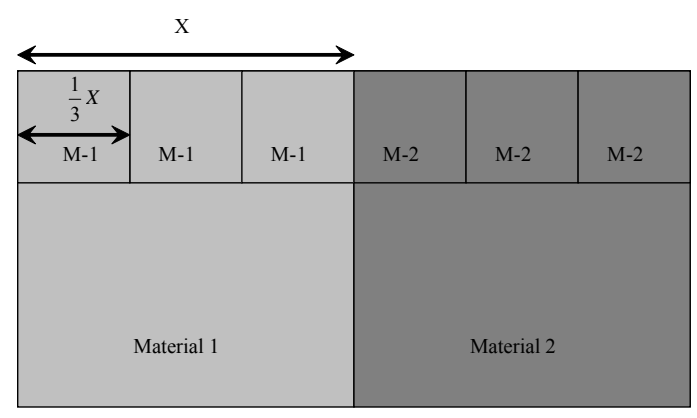

(a)

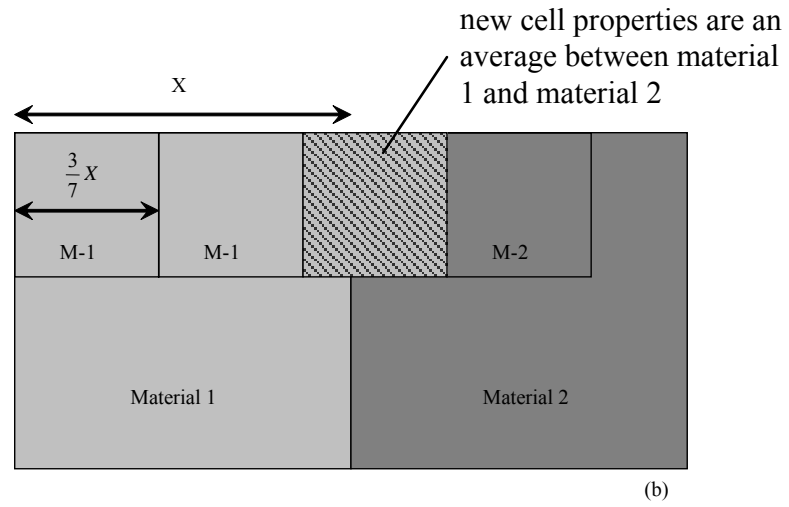

Figure 7. Designation of original cell properties (M-1 and M-2) to refined cells when refined cells are (a) a multiple of the original cell size, and (b) not a multiple of the original cell size.

\section{Refined Grid Properties/Modification to MODFLOW-2000 Input Files}

Below is a discussion of modifications made to various MODFLOW-2000 input files to establish cell-by-cell properties for the refined grid. Two separate simulations were run with the refined grid. The first simulation was over the same time frame (years 1913 to 1998, or 86 years) and with the same stresses as the original DVRFSM. This simulation compares final output heads between the original model and the refined model for accuracy. The second simulation began with current conditions and extended forward 75 years. Two scenarios are run given the 75-year forward simulation. One scenario includes the addition of the VWC and SNWA pumping wells, while the other scenario does not include these additional wells.

\section{IBOUND Array}

MODFLOW-2000 designates cells with an IBOUND array to distinguish cells as active (IBOUND $>1$ ) or inactive/no flow (IBOUND $\leq 0$ ). All cells in the refined model domain were designated as an IBOUND $=1$ except for those in the southeast corner, which were set to IBOUND $=0$ because they fell outside the original model domain. The IBOUND array is the same for both the original 86-year simulation and the 75-year forward simulation.

\section{$\underline{\text { Starting Heads and Layer Elevations }}$}

Starting heads for the original 86-year simulation were extracted from the original DVRFSM starting heads file. This was done by assigning the original cell value to all nine refined cells (see Figure 8). No attempt was made to interpolate heads across the suite of nine 
cells. Likewise, the starting heads for the 75-year forward run were extracted from the final heads of the original DVRFSM. Layer elevations were assigned in a similar manner as starting heads.

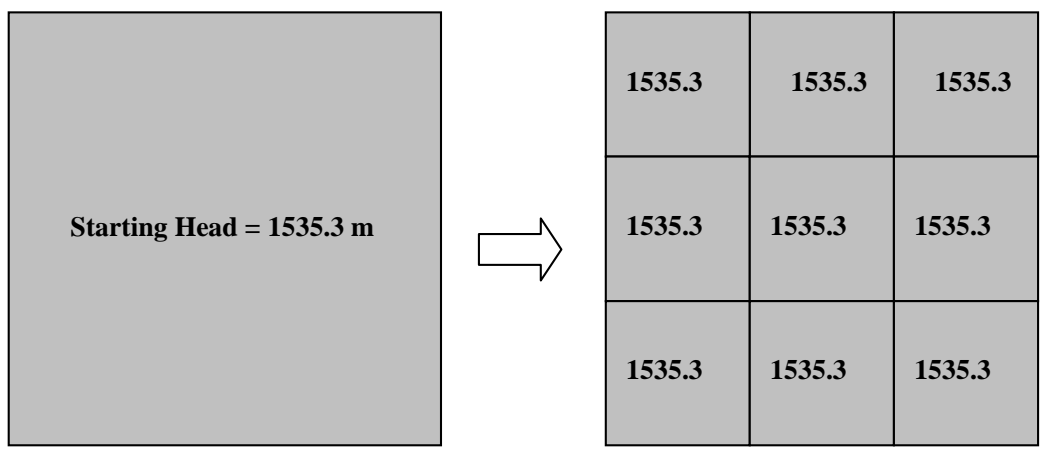

Figure 8. An example of assigning a starting head from the original grid to the refined grid.

\section{$\underline{\text { Constant Head Boundary }}$}

Final heads from the original DVRFSM (i.e., current conditions) that aligned with the outer boundary of the refined grid, as defined by the IBOUND array (see Figure 9), were assigned to the refined grid. Figure 9 shows that the constant heads were assigned only to those refined cells that were adjacent to "no-flow" cells (IBOUND $\leq 0$ ) and not to all nine refined cells representing the original constant head cell. Constant heads were the same for both the original 86-year simulation and the 75-year forward simulation.

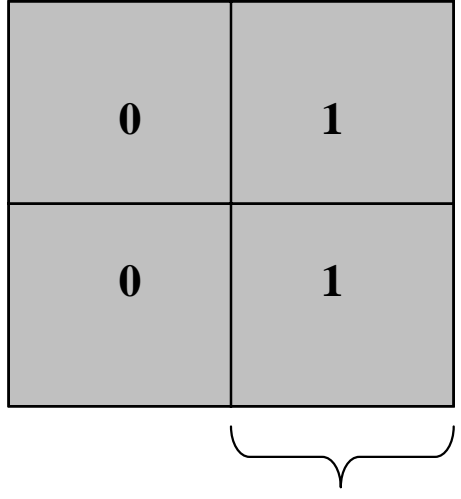

Specified Head Cells

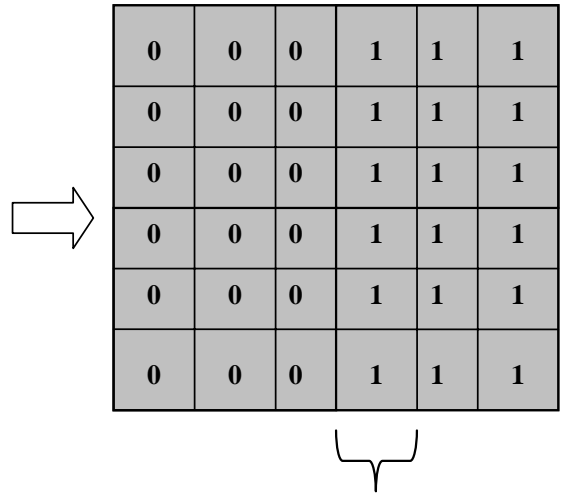

Specified Head Cells

Figure 9. Example of assigning constant head cells from the original grid to the refined grid.

\section{$\underline{\text { Drains }}$}

Drains are used in the DVRFSM to represent regions of groundwater discharge either by ET or spring flow. MODFLOW-2000 defines drains based on cell location, elevation and conductivity. Drains located outside the refined model domain were discarded, while those 
located within the refined model domain were assigned from a single original cell to the nine representative cells of the refined grid. Both elevation and conductance values were assigned to the refined grid in a manner similar to starting heads (see Figure 8). The same drain input file was used for the original 86-year simulation and the 75-year forward simulation.

\section{Faults}

Nine faults are modeled with the HFB package in the original DVRFSM. Of these nine faults, all or portions of seven faults are contained within the refined model domain. The HFB package assumes that flow barriers are thin regions between two finite-difference cells on the same model layer. The hydraulic characteristic of these faults are computed as the hydraulic conductivity of the barrier multiplied by the vertical thickness of the cell. The conductance term is independent of the cell length, and since no refinement was made in cell thickness, the conductance term is directly transferable from the original DVRFM to the refined model. The HFB cells were assigned to all refined cells, defining the edge of an original cell where an HFB existed (see Figure 10). The HFB cells, however, were excluded from the refined grid if they fell along the model's boundary. The same HFB input file was used for the original 86-year simulation and the 75-year forward simulation.
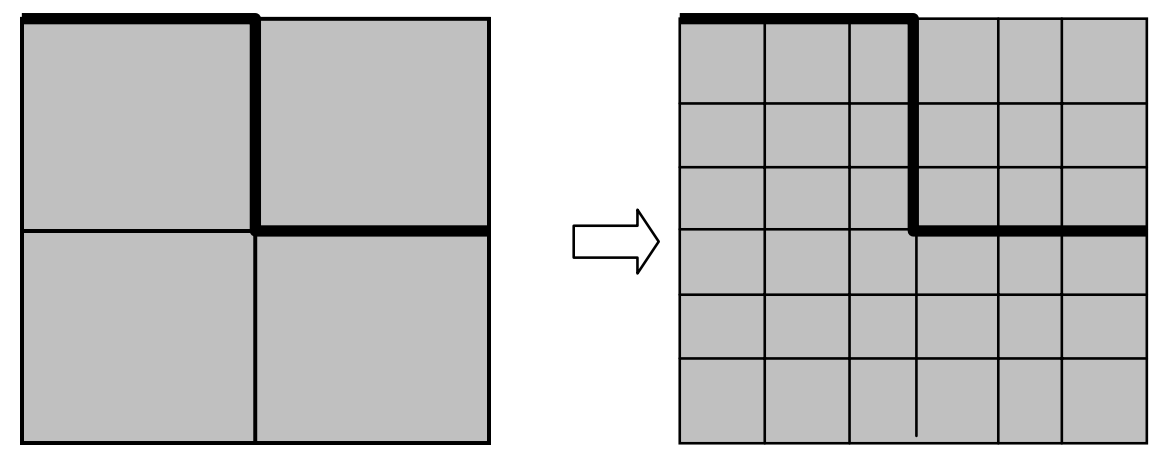

Figure 10. Example of assigning horizontal flow barrier (HFB) cells from the original grid to the refined grid.

\section{Hydrogeologic Unit Flow}

Despite the complexity of the three-dimensional hydrogeologic framework of the DVRFS and relative complexity of the associated HUF2 package used to describe the system, the translation of the HUF physical and hydrologic properties from the original grid to the refined grid was straightforward. Unit top elevations and thicknesses were assigned with a similar process as starting heads (see Figure 8), as were zone arrays defining portions of each unit. The same HUF2 input file was used for the original 86-year simulation and the 75-year forward simulation.

\section{Multi-node Wells}

The input file for the Multi-node Well (MNW) package (Halford and Hanson, 2002) was rewritten such that the well locations in the refined model were placed in the center of the nine-cell array defining the original cell. In this manner, all pumping rates from the original model were maintained in the refined model. For the comparison run between the original DVRFSM and the refined model, all stresses pertaining to the each of the original 86 
years were kept. To simulate the 75-year forward run, only the well stresses from the final timestep (1998, or current conditions) were used. The MNW file, however, slowed computation time dramatically for the 75-year forward run and was eventually discarded for the equivalent MODFLOW WELL package file generated by the DVRFSM. The 14 proposed wells were added to the WELL file with information provided in Table 3. All wells were placed in layer 1 . The top of layer 1 represents the water table surface, while the depth of layer 1 (provided in Table 3) represents the maximum extent of assumed drilling for each well.

Table 3. Locations and pumping rates of SNWA and VWC proposed wells.

\begin{tabular}{|c|c|c|c|c|c|c|c|}
\hline \multirow[b]{2}{*}{ Well ID } & \multicolumn{2}{|c|}{ UTM } & \multicolumn{3}{|c|}{ Grid Locations } & \multicolumn{2}{|c|}{ Discharge } \\
\hline & East & North & $\begin{array}{c}\text { Layer } 1 \\
\text { depth } \\
\text { (m) }\end{array}$ & Row & Column & $\left(\mathrm{m}^{3} / \mathrm{d}\right)$ & (acre-ft/year) \\
\hline SNWA-1 & 603233.8 & 4045270 & 127.3 & 117 & 156 & $14,679.5$ & 4,347 \\
\hline SNWA-2 & 604873 & 4045252 & 150.1 & 117 & 159 & $14,679.5$ & 4,347 \\
\hline SNWA-3 & 606442.4 & 4045322 & 167.7 & 117 & 162 & $14,679.5$ & 4,347 \\
\hline SNWA-4 & 608098.9 & 4045357 & 131.4 & 117 & 166 & $14,679.5$ & 4,347 \\
\hline SNWA-5 & 609703.2 & 4045409 & 96.3 & 117 & 169 & $14,679.5$ & 4,347 \\
\hline SNWA-6 & 611394.7 & 4045392 & 57.0 & 117 & 172 & $14,679.5$ & 4,347 \\
\hline SNWA-7 & 613068.7 & 4045340 & 54.5 & 117 & 176 & $14,679.5$ & 4,347 \\
\hline VWC-1 & 588084.8 & 4049505 & 137.4 & 108 & 126 & $4,159.2$ & 1,232 \\
\hline VWC-2 & 586766.8 & 4047923 & 83.1 & 112 & 123 & $4,159.2$ & 1,232 \\
\hline VWC-3 & 587237.5 & 4046342 & 82.8 & 115 & 124 & $4,159.2$ & 1,232 \\
\hline VWC-4 & 592961.6 & 4049486 & 78.2 & 109 & 135 & $4,159.2$ & 1,232 \\
\hline VWC-5 & 591718.9 & 4047923 & 82.2 & 112 & 133 & $4,159.2$ & 1,232 \\
\hline VWC-6 & 590118.4 & 4045174 & 85.8 & 117 & 130 & $4,159.2$ & 1,232 \\
\hline VWC-7 & 592679.2 & 4043819 & 93.0 & 120 & 135 & $4,159.2$ & 1,232 \\
\hline
\end{tabular}

$\underline{\text { Recharge }}$

To reassign recharge values across the refined grid, the recharge multiplier array (rch1_modmd.asc) and zone array (infil_zone_9.asc) were modified in a similar manner as starting heads (see Figure 8).

\section{POST-PROCESSING}

MODPATH (Pollock, 1994) is a post-processing routine that computes threedimensional flowpaths using output from the MODFLOW finite-difference groundwater flow model. MODPATH is capable of assimilating output from either transient or steadystate simulations. The DVRFSM is calibrated in double-point precision and binary files generated by MODFLOW were initially unreadable by MODPATH. Therefore, it was necessary to recompile MODPATH in double-point precision such that communication could occur between programs. MODPATH also requires that all heads and budgets be saved to the compact budget file at every timestep. For a large three-dimensional model such as the DVRFSM, as well as its refined counterpart, it becomes necessary to reduce the number of timesteps for MODPATH to run correctly. 
Groundwater Modeling Systems (GMS) provides a graphical user interface to develop, run, and/or analyze MODFLOW groundwater models. Unfortunately, GMS has not implemented several components of MODFLOW-2000 (most notably HUF2) and it cannot use parameter groups or read double-precision binary files. Therefore the DVRFSM and the refined model were run outside of GMS and output imported into GMS for visualization purposes only.

\section{RESULTS}

\section{Comparison between Original and Refined Models}

To test the effectiveness of the refined model, it is important that results from the refined model replicate results from the original model. Figure 11 displays heads produced by each model at the simulation's final timestep. Visual inspection shows the two models produce similar head maps for the same stress period. A minimum head of $-52.5 \mathrm{~m}$ is simulated in both models. A maximum head of 2,807.5 $\mathrm{m}$ and 2,789.5 $\mathrm{m}$ for the DVRFSM and the refined model, respectively, shows that the refined model is underpredicting heads in the southeast portion of the model by $18 \mathrm{~m}$. The spatial distribution of error is presented in Figure 12. Error was computed by subtracting DVRFSM heads from the refined model heads. The distinct bands of error alternating from positive to negative is the result of steep gradients such that the refined grid gradients intersect the much larger DVRFSM cells and their representation of head. General trends show that the refined model is overpredicting heads in the southwest corner but underpredicting heads in the remainder of the modeled region when compared to the DVRFSM. Error associated with the refined model, however, is generally less than $\pm 5 \mathrm{~m}$ as shown with the green shades in Figure 12. The average error is $-2.9 \mathrm{~m}$ over the entire modeled domain. Therefore, it is assumed the refined model is an appropriate tool for looking at potential stress impacts caused by additional SNWA and VWC wells.

\section{Effects of Additional Pumping}

Using the refined grid, 75 years of proposed pumping by SNWA and VWC were compared to the same 75 years with no additional pumping. Pumping was initiated at the end of the original DVRFSM, the equivalent of year 1999.

\section{Water Levels/Drawdown}

Figure 13 shows results in terms of excess drawdown. Excess drawdown is the amount of drawdown obtained with additional pumping minus the drawdown obtained with no additional pumping. The areal extent of $0.5 \mathrm{~m}$ of drawdown is depicted in gray with contour lines of $10 \mathrm{~m}$ also shown. Several Nevada administrative groundwater basins near the NTS are outlined and marked. Drawdown appears extensive with significant impacts on Mercury Valley, Amargosa, Indian Springs, Three Lakes, and Frenchman Flat basins. The area impacted by drawdown becomes larger with successively deeper layers in the model, with the bottom layer showing the widest extent of $0.5-\mathrm{m}$ drawdown. This is most likely the result of reduced hydraulic conductivity with depth (KDEP package). Pahrump Valley is therefore impacted at depth. The SNWA wells are located just south of the Las Vegas shear zone (see Figure 13b), resulting in very limited drawdown to the north of these faults. 


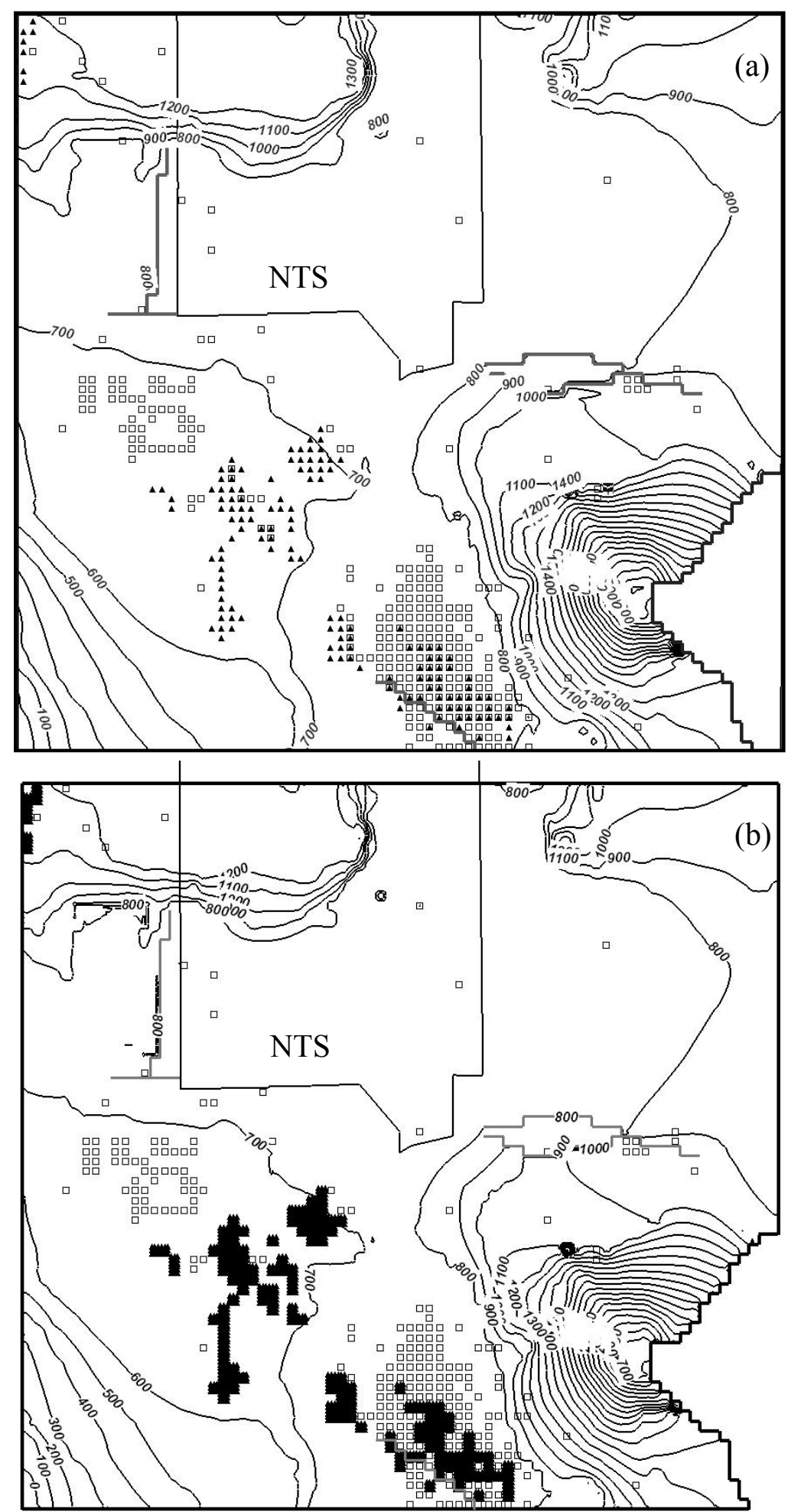

Figure 11. Visual comparison of top layer final heads for 1998 pumping con original DVRFSM and (b) refined model. Included are symbols d well (open square), drain (black triangle), or fault (thick gray line ions between (a) icting if a cell is a for reference (black line) and head intervals are $100 \mathrm{~m}$.

The NTS is included 

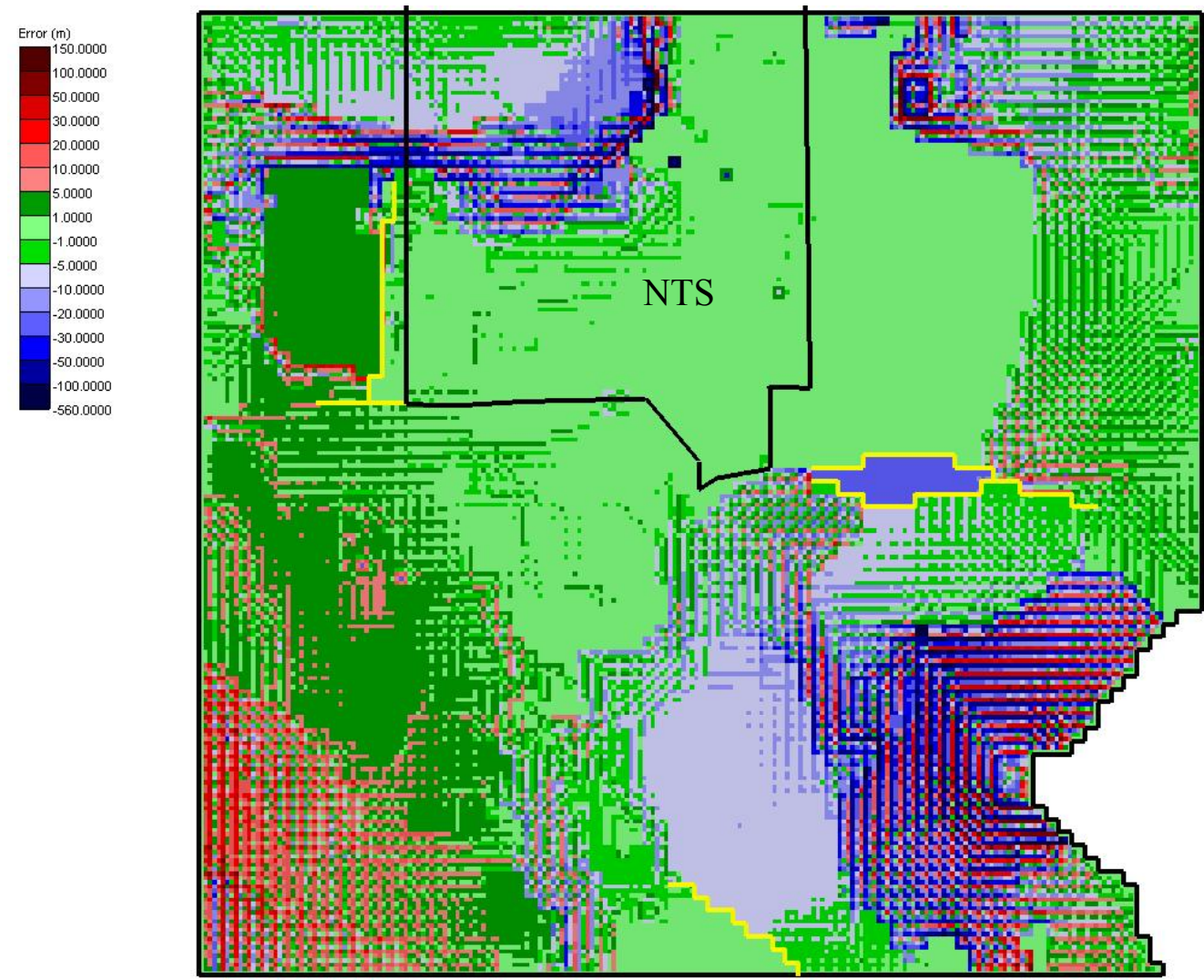

Figure 12. Spatially distributed error (m) computed as refined grid head minus DVRFSM head.

Drawdown in the top layer, over time, at well locations is shown in Figure 14. The SNWA proposed wells have excess drawdown ranging from approximately $200 \mathrm{~m}$ to 1,000 $\mathrm{m}$ within a 75-year period, while VWC wells experience $8 \mathrm{~m}$ to 1,600 $\mathrm{m}$ of excess drawdown over the same pumping period. The more limited areal extent of VWC wells coupled with extreme drawdown is probably the result of lower hydraulic conductivity or specific yield in the vicinity of these wells. In contrast, the only VWC well (VWC-1) with relatively little drawdown is probably located in a separate material with much higher hydraulic conductivity or specific yield.

\section{$\underline{\text { Water Levels/Drawdown }}$}

Figure 13 shows results in terms of excess drawdown. Excess drawdown is the amount of drawdown obtained with additional pumping minus the drawdown obtained with no additional pumping. The areal extent of $0.5 \mathrm{~m}$ of drawdown is depicted in gray with contour lines of $10 \mathrm{~m}$ also shown. Several Nevada administrative groundwater basins near the NTS are outlined and marked. Drawdown appears extensive with significant impacts on Mercury Valley, Amargosa, Indian Springs, Three Lakes, and Frenchman Flat basins. The area impacted by drawdown becomes larger with successively deeper layers in the model, with the bottom layer showing the widest extent of $0.5-\mathrm{m}$ drawdown. This is most likely the 


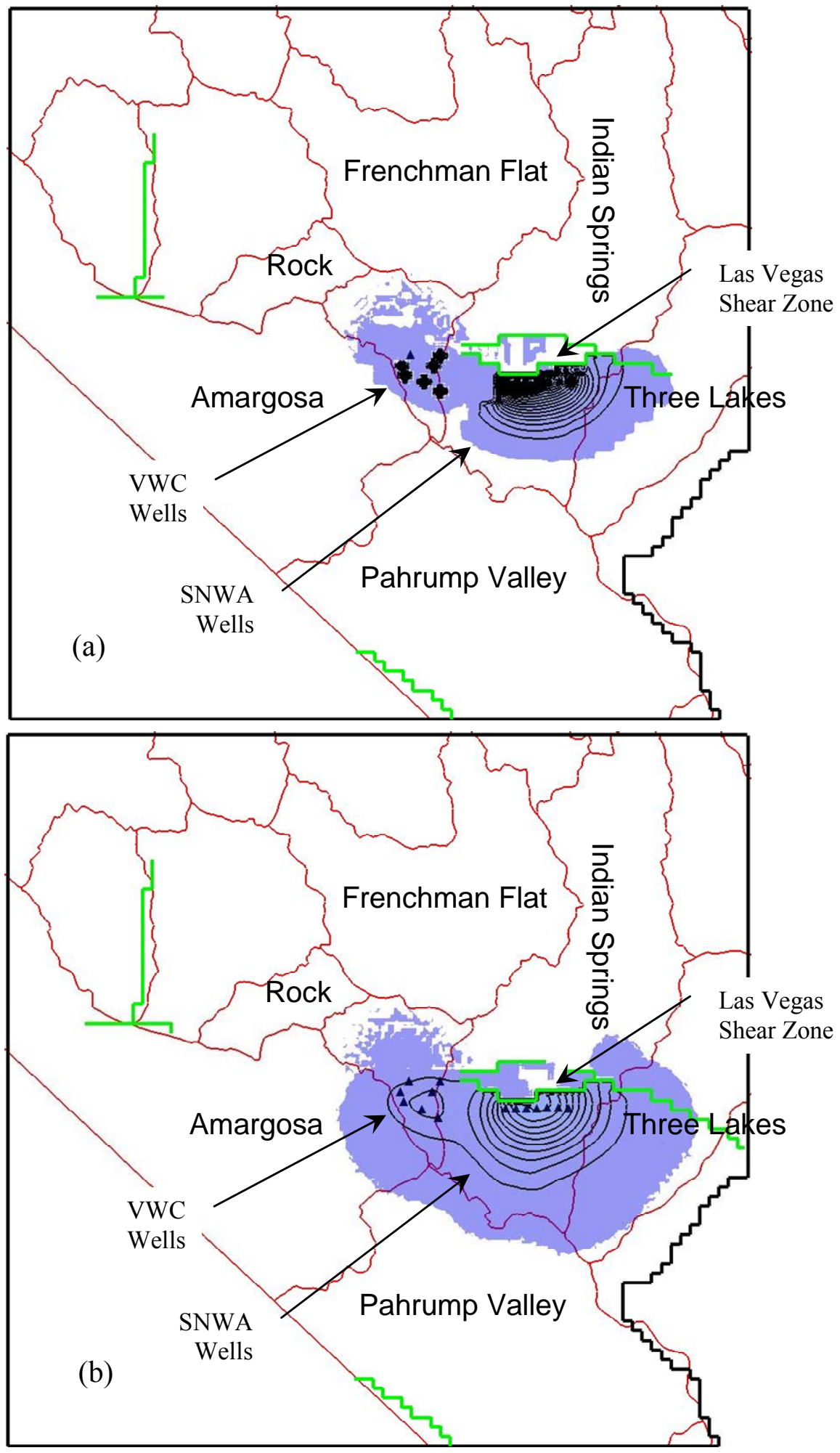

Figure 13. The areal extent of the $0.5 \mathrm{~m}$ contour (blue shaded region) for excess drawdown from additional pumping of proposed VWC and SNWA wells for (a) the top layer and (b) the bottom layer. Included are hydrogeographic basins (thin red lines), and shear zones (thick green lines) with the Las Vegas Shear Zone identified. Thin black lines represent $10 \mathrm{~m}$ contours of drawdown. 
result of reduced hydraulic conductivity with depth (KDEP package). Pahrump Valley is therefore impacted at depth. The SNWA wells are located just south of the Las Vegas shear zone (see Figure 13b), resulting in very limited drawdown to the north of these faults. Drawdown in the top layer, over time, at well locations is shown in Figure 14. The SNWA proposed wells have excess drawdown ranging from approximately $200 \mathrm{~m}$ to $1,000 \mathrm{~m}$ within a 75-year period, while VWC wells experience $8 \mathrm{~m}$ to $1,600 \mathrm{~m}$ of excess drawdown over the same pumping period. The more limited areal extent of VWC wells coupled with extreme drawdown is probably the result of lower hydraulic conductivity or specific yield in the vicinity of these wells. In contrast, the only VWC well (VWC-1) with relatively little drawdown is probably located in a separate material with much higher hydraulic conductivity or specific yield
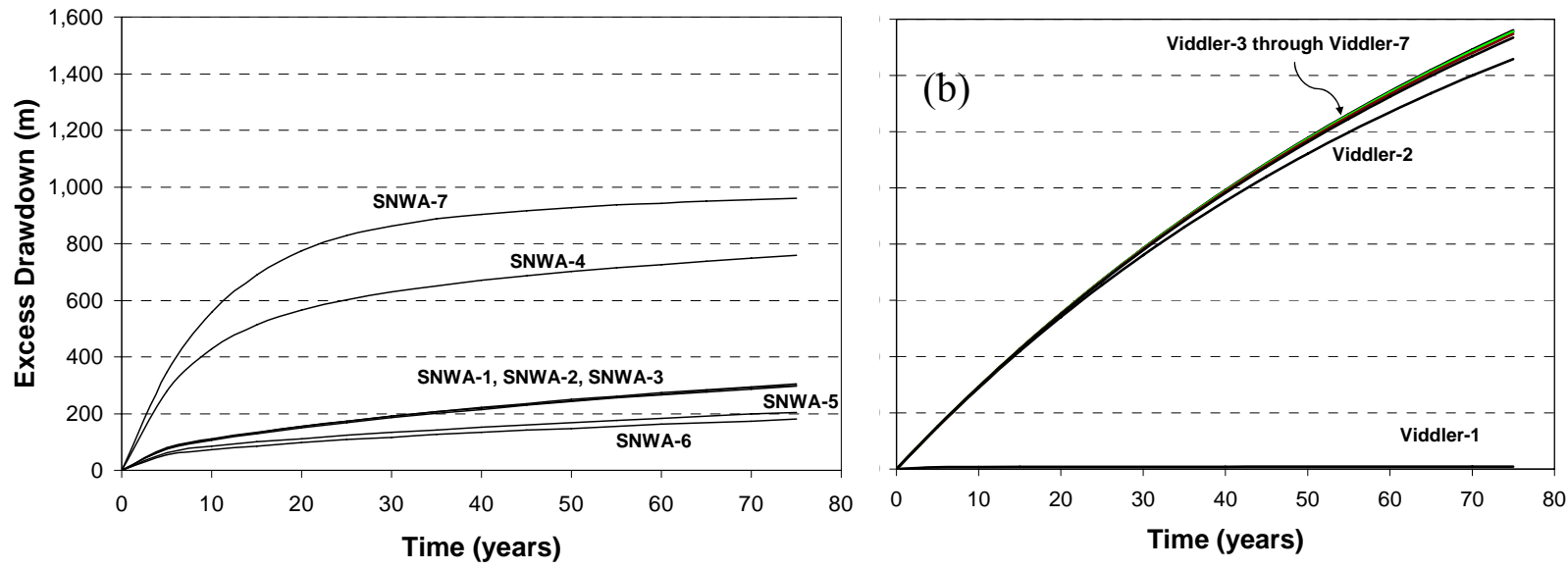

Figure 14. Excess drawdown over time at pumping well locations (a) SNWA and (b) VWC. Well locations are provided in Table 3.

\section{NTS Groundwater Resources}

Figure 15 shows the locations of NTS water-supply wells in relation to the areal extent of excess drawdown in layer 1 caused by the proposed wells. A visual inspection shows that most of the NTS wells are not significantly impacted by the addition of SNWA and VWC wells, the exception being Army \#1 Water Well, located at the southern tip of the NTS (Mercury basin). A closer look at drawdown was conducted by extracting drawdown from each NTS well location. The differences in drawdown between additional pumping and no additional pumping are provided in Table 4. Results confirm significant impact to Army \#1 Water Well with $2 \mathrm{~m}$ of drawdown generated from the additional pumping. Other wells are only minimally impacted. 


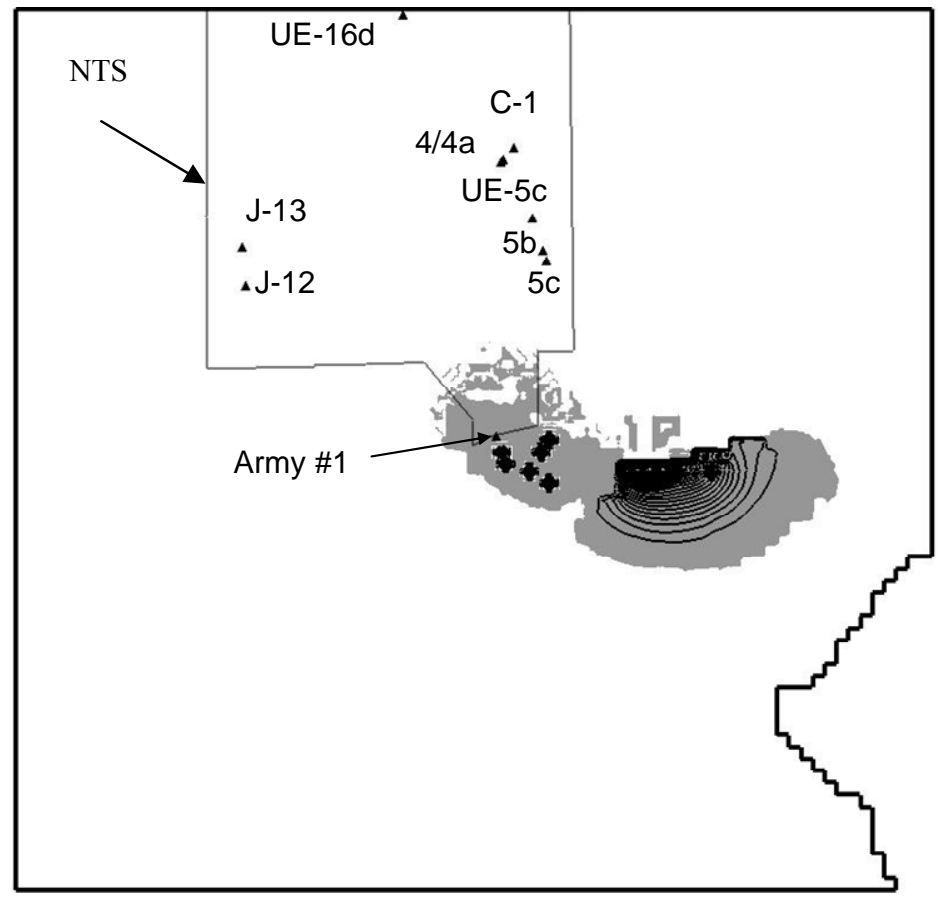

Figure 15. Locations of operating NTS pumping wells in relation to areal extent of excess drawdown in layer 1.

Table 4. Excess drawdown at NTS water-supply wells caused by additional pumping at proposed SNWA and VWC wells.

\begin{tabular}{cccc}
\hline Basin & Well & Layer & Drawdown (m) \\
\hline Mercury Valley & ARMY\#1 & 1 & 2.1 \\
& & 2 & 2.1 \\
& & 3 & 2.1 \\
Frenchman Flat & 4 & 2.1 \\
& & 5 & 2.1 \\
\hline & & 3 & 0.1 \\
& & 4 & 0.1 \\
& & 5 & 0.1 \\
& & 6 & 0.2 \\
& & 7 & 0.2 \\
& & 8 & 0.2 \\
& & 2 & 0.1 \\
& & 2 & 0.1 \\
& & 3 & 0.2 \\
& $4 / 4 \mathrm{a}$ & 4 & 0.2 \\
& & 1 & 0.2 \\
& & 2 & 0 \\
& & 3 & 0.1 \\
& & 4 & 0.1 \\
& & 2 & 0.1 \\
& & 3 & 0.1 \\
\hline
\end{tabular}


Table 4. Excess drawdown at NTS water-supply wells caused by additional pumping at proposed SNWA and VWC wells (continued).

\begin{tabular}{|c|c|c|c|}
\hline Basin & Well & Layer & Drawdown (m) \\
\hline \multirow[t]{13}{*}{ Jackass Flats } & $\mathrm{J}-12$ & 1 & 0.1 \\
\hline & & 2 & 0 \\
\hline & & 3 & 0 \\
\hline & $\mathrm{J}-13$ & 1 & 0 \\
\hline & & 2 & 0 \\
\hline & & 3 & 0 \\
\hline & & 4 & 0.1 \\
\hline & & 5 & 0 \\
\hline & & 6 & 0 \\
\hline & & 7 & 0.1 \\
\hline & & 8 & 0 \\
\hline & & 9 & 0.2 \\
\hline & & 10 & 0.2 \\
\hline \multirow[t]{7}{*}{ Yucca Flat } & UE-d16 & 3 & 0 \\
\hline & & 4 & 0 \\
\hline & & 5 & 0 \\
\hline & & 6 & 0 \\
\hline & & 7 & 0 \\
\hline & & 8 & -0.1 \\
\hline & & 9 & 0 \\
\hline
\end{tabular}

\section{$\underline{\text { Volumetric Budget }}$}

A review of the cumulative volumetric budget for the entire 75-year simulation is provided in Table 5. More than 99 percent of the water needed to supply the SNWA and VWC proposed wells is derived from storage, with nearly negligible amounts pulled across the constant head boundaries and/or taken from drains (i.e., springs and regions of groundwater ET). The 0.19 -percent reduction to drains over 75 years equals a little more than 4 million cubic meters $(3,364$ acre-ft/75-years). The resulting annual average reduction is $55,326 \mathrm{~m}^{3} /$ year (45 acre-ft/year). This study does not address which springs might be impacted the most, or what may represent a significant reduction to these ecologically sensitive zones.

\section{Flowpaths from the NTS}

Finally, an investigation of flowpaths from underground nuclear tests was conducted. Three test locations exist within the refined model domain: Gum Drop, Cumarin, and Diluted Waters. Initial attempts to look at flowpaths from these locations showed that 75 years was insufficient to have particles move beyond one cell length. Steady-state simulations, however, allow for "unlimited" travel time and so were used to determine flowpaths. Transient drawdown conditions reach steady-state drawdown after approximately 50,000 years of pumping. Figure 16 shows drawdown after 75 years of pumping compared to steady-state drawdown. On average, SNWA wells reach 23 percent of their steady-state values in 75 years, while VWC wells reach 42 percent of their steady-state drawdown values. Therefore, in all cases, steady-state conditions represent significantly more drawdown than obtained in 75 years. 
Table 5. A comparison of cumulative volumetric budget for the 75-year forward scenario given no additional pumping and additional pumping wells.

\begin{tabular}{|c|c|c|c|c|c|c|}
\hline & \multicolumn{2}{|c|}{ Volume ( $\mathrm{m}^{3} / 75$ years) } & \multicolumn{2}{|c|}{ Difference } & \multirow{2}{*}{$\begin{array}{l}\text { \% of Well } \\
\text { Discharge }\end{array}$} \\
\hline & & No Wells (1) & Added Wells (2) & (2) - (1) & $\%$ & \\
\hline \multirow{6}{*}{ 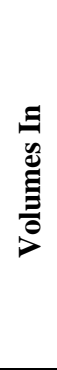 } & Storage & $7,741,118,652$ & $11,282,309,644$ & $3,541,190,992$ & 45.75 & 98.03 \\
\hline & Constant Heads & $4,521,260,879$ & $4,531,542,428$ & $10,281,549$ & 0.23 & 0.28 \\
\hline & Wells & $990,579,431$ & $990,579,431$ & 0 & 0 & 0.00 \\
\hline & Drains & 0 & 0 & 0 & 0 & \\
\hline & Recharge & $2,318,211,420$ & $2,318,211,420$ & 0 & 0 & \\
\hline & Total In & $15,571,170,382$ & $19,122,642,923$ & $3,551,472,541$ & 22.81 & \\
\hline \multirow{6}{*}{ 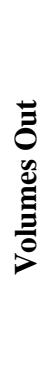 } & Storage & $4,198,449,955$ & $4,141,786,054$ & $-56,663,900$ & -1.35 & 1.57 \\
\hline & Constant Heads & $3,102,923,418$ & $3,102,684,523$ & $-238,895$ & -0.01 & 0.01 \\
\hline & Wells & $6,109,862,480$ & $9,722,300,946$ & $3,612,438,467$ & 59.12 & \\
\hline & Drains & $2,163,285,068$ & $2,159,135,644$ & $-4,149,424$ & -0.19 & 0.11 \\
\hline & Recharge & 0 & 0 & 0 & 0 & \\
\hline & Total Out & $15,574,520,920$ & $19,125,907,168$ & $3,551,386,248$ & 22.80 & \\
\hline \multirow{2}{*}{ 方 } & In - Out & $-3,350,539$ & $-3,264,245$ & & & \\
\hline & \% Discrepancy & -0.02 & -0.02 & & & \\
\hline
\end{tabular}

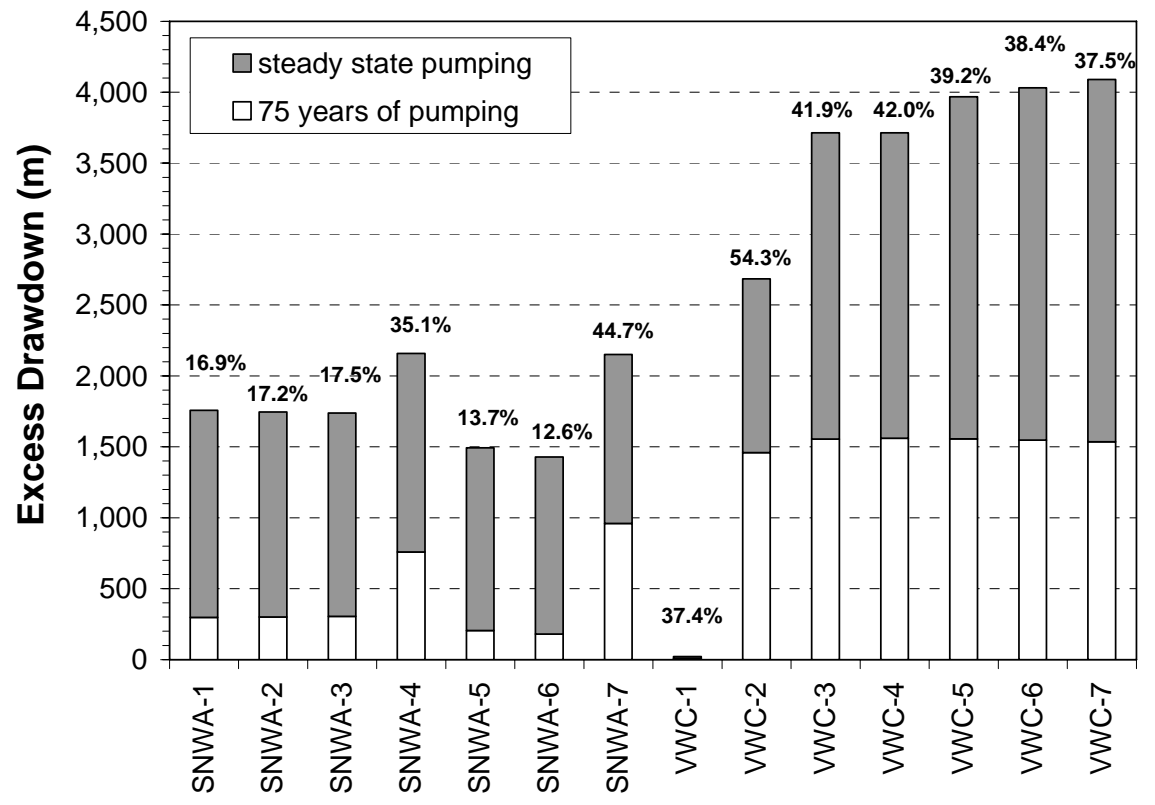

Figure 16. The relative amount of drawdown in proposed pumping wells after 75 years of pumping compared to steady-state drawdown values. 
Steady-state pathlines, given both no additional pumping (black paths) and additional pumping (red paths), are compared in Figure 17. These flowpaths are superimposed on a map of excess drawdown (drawdown with additional wells - drawdown with no additional wells); the NTS boundary is shown for reference. A change in flow direction is simulated for all pathlines originating from the three detonation sites. The least amount of variation occurs at Diluted Waters, with the pathline pulled only slightly to the south and east and terminating at the same location in Frenchman Flat as is predicted given no additional pumping. In both scenarios, Diluted Waters' pathlines remain entirely within the NTS. Flow from Gum Drop is likewise pulled slightly to the south and east by additional pumping and terminates in Amargosa Valley (outside the NTS) by approximately $250 \mathrm{~m}$ to the southeast of its predicted destination without pumping. Finally, the pathline originating at Cumarin is most altered. With no additional pumping, flow from Cumarin is predicted to converge at the same location as flow from Diluted Waters' and Cumarin's entire pathline is contained within the NTS. Additional pumping, however, causes the Cumarin flowpath to arc around Diluted Water, through the Mercury Valley basin, out of the NTS, and into Amargosa Valley. One is reminded that the pathlines in Figure 17 are for steady-state conditions, which represent more extreme drawdown values obtained over much longer periods of time than the 75-year forward scenario. However, slight changes in drawdown (less than $0.5 \mathrm{~m}$ ) may significantly alter the flowpath originating from Cumarin. It is also notable that the current model representation of the Las Vegas shear zone prevents northward-migrating drawdown from the SNWA wells. If this barrier to flow was limited, or even removed, much greater deviation of flowpaths toward the southeast would be expected.

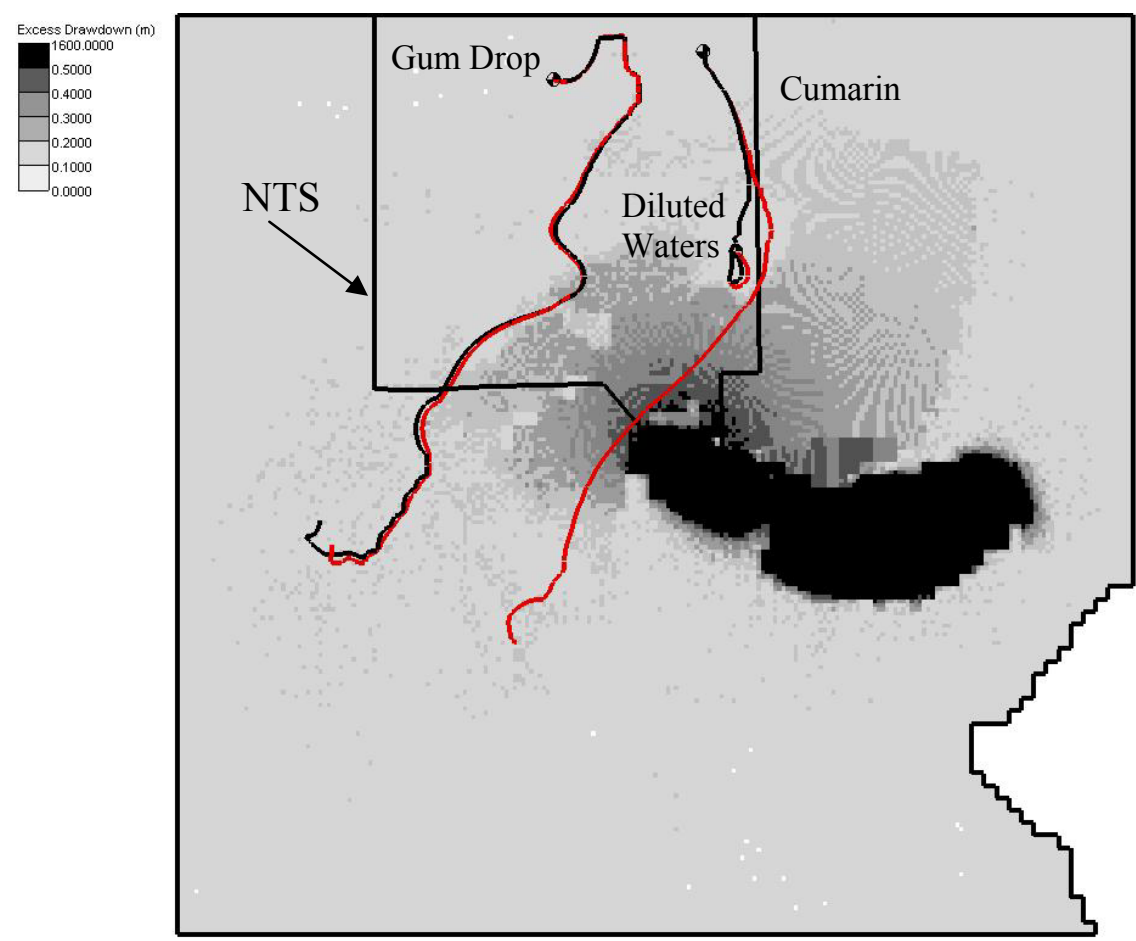

Figure 17. Comparison of steady-state pathlines from three NTS detonation sites superimposed on a map of excess drawdown. Black pathlines represent flow given no additional pumping and red pathlines represent flow given additional pumping. 


\section{MODEL LIMITATIONS}

One limitation of the DVRFSM is the use of the confined layer assumption. The use of the confined, rather than "convertible" (i.e. unconfined), layer type within MODFLOW2000 assumes that the saturated thickness remains constant throughout the entire simulation. Therefore, cells are not allowed to dry or become inactive as the water level decreases below the bottom of a cell. The confined approach was adopted by the USGS because the model was computationally unstable when cells were allowed to convert between confined and unconfined. Unfortunately, the confined approach, while numerically stable, allows unrealistic estimates of drawdown to occur.

The use of the HUF2 package allows one to apply an unconfined storage parameter (specific yield) for cells near the water table such that water is removed from storage at the appropriate rate. Although the HUF2 package accounts for storage properly in cells near the water table under quasi-steady-state conditions, large drawdown induced by pumping causes the an improper assignment of groundwater storage near areas of large drawdown. In reality, the specific yield should be applied to those cells located at the phreatic surface, which is constantly changing in time and space. Unfortunately, one cannot properly simulate the effects of groundwater storage unless convertible cells are used.

Another potential limitation of the model is the fact that the fault hydraulic properties were calibrated under limited groundwater stress. The effects faults have on pumpinginduced drawdown cannot be known until a real-world stress is applied and hydraulic heads monitored across the faults. As was shown in these simulations, the faults act as barriers to flow, which causes the drawdown response to be reflected to the side in which pumping occurs.

\section{CONCLUSIONS}

A refined model was developed from the DVRFSM model to investigate potential impacts of 14 additional pumping wells placed just south of the NTS. Cell size was reduced from $1,500 \mathrm{~m}$ to $500 \mathrm{~m}$ to examine the impacted area in greater detail. The model domain was also reduced to balance the need to fully encompass the impacted region and limit boundary interactions with drawdown. Constant heads were altered by less than 0.3 percent, signifying that boundary effects on modeled drawdown were negligible.

The refined model was run under the same conditions as the original 86-year DVRFSM to evaluate its effectiveness. Results show that the refined model adequately mimics the original model and is considered a viable tool in assessing additional pumping in the region.

Assuming that permits are allocated for 75 years, simulations were run for 75 years given both no additional pumping and additional pumping. Excess drawdown was significant for most wells (200 to 1,600 m) with at least $0.5 \mathrm{~m}$ of drawdown impactting the Mercury Valley, Amargosa, Indian Springs, Three Lakes, and Frenchman Flat basins. The areal extent of excess drawdown $(\geq 0.5 \mathrm{~m})$ is larger with successively deeper layers in the model with the bottom-most layer showing the widest extent. Simulated drawdown northward of the SNWA wells was limited by the Las Vegas shear zone. The impact of additional pumping on NTS water-supply wells is restricted to Army \#1 Water Well located in the Mercury Valley basin, which may experience $2.1 \mathrm{~m}$ of additional drawdown. Nearly all water extracted from the 
model via additional wells is produced from groundwater storage. Only a slight reduction $(0.19 \%)$ of spring discharge and regions of groundwater ET is estimated given additional pumping. A 0.19 percent reduction is equal to approximately $55,000 \mathrm{~m}^{3}$ (45 acre- $\left.\mathrm{ft} / \mathrm{year}\right)$. This study does not examine the impact of this reduction on individual springs or address what is ecologically significant.

Steady-state flowpaths beginning at the Gum Drop, Cumarin and Diluted Waters underground nuclear test locations are impacted by additional SNWA and VWC pumping. The greatest departure in flowpath direction occurs with flow originating at Cumarin and terminating outside of the NTS in the Amargosa basin. While steady-state conditions represent much larger drawdowns and longer time frames than occur during 75 years of pumping, it is recognized that that flow is altered by less than $0.5 \mathrm{~m}$ of excess drawdown and may be limited by the current model representation of the Las Vegas shear zone.

\section{FUTURE WORK}

Future modeling efforts will focus on three objectives. First, continued model development will occur. Specifically, updated recharge estimates from the deuterium-calibrated discrete-state compartment model (Campana, 1975) will be input to the DVRFSM. Recharge was as a calibration parameter; therefore, it is necessary to assess the impacts of new recharge values on calibration as well as model output. Additionally, MODFLOW-2005 will aid in refining the DVRFSM with its telescoping capabilities. In this manner, the solution of the larger model and the smaller refined model boundary conditions are coupled. The second objective is to quantify uncertainty in the refined model output associated with model location and cell refinement in the horizontal and vertical dimension. It will be necessary to derive a relationship between domain extent and cell size to remove boundary condition effects on simulated drawdown. This relationship will be quantified and used to distinguish between reliable and unreliable model structures for use in Monte Carlo analysis. Monte Carlo analysis will allow the determination of a 90-percent confidence interval for (1) expected drawdown, (2) areal extent of 0.5-m drawdown, and (3) change to spring discharge. Finally, ecologically sensitive regions will be identified and examined in the context of the uncertainty analysis. 


\section{REFERENCES}

Anderman, E.R. and M.C. Hill, 2000. MODFLOW-2000, the U.S. Geological Survey modular ground-water model -- Documentation of the Hydrogeologic-Unit Flow (HUF) Package: U.S. Geological Survey Open-File Report 00-342, 89 p.

Anderman, E.R. and M.C. Hill, 2003. MODFLOW-2000, the U.S. Geological Survey modular ground-water model -- Three additions to the Hydrogeologic-Unit Flow (HUF) Package: Alternative storage for the uppermost active cells, Flows in hydrogeologic units, and the hydraulic-conductivity depth-dependence (KDEP) capability: U.S. Geological Survey Open-File Report 03-347, 36 p.

Belcher, W, R., F.A. D'Agnese, and G.M. O'Brian, 2004. Introduction. Chapter D of Death Valley Regional Groundwater Flow System, Nevada and California - Hydrogeologic Framework and Transient Groundwater Flow Model. U.S. Geological Survey Scientific Investigations Report 2004-5205. Pp. 3-20.

Campana, M.E., 1975. Finite-state models of transport phenomena in hydrologic systems, $\mathrm{PhD}$ dissertation: University of Arizona, Tucson.

D'Agnese, F.A., C.C. Faunt, A.K. Turner, and M.C. Hill, 1997. Hydrogeologic evaluation and numerical simulation of the Death Valley regional groundwater flow system, Nevada and California: U.S. Geological Survey Water-Resources Investigations Report 96-4300. $124 \mathrm{p}$.

Faunt, C.C., F.A. D'Agnese, and G.M. O'Brian, 2004a. Hydrology. Chapter D of Death Valley Regional Groundwater Flow System, Nevada and California - Hydrogeologic Framework and Transient Groundwater Flow Model. U.S. Geological Survey Scientific Investigations Report 2004-5205. Pp. 137-164.

Faunt, C.C., D.S. Sweetkind, and W.R. Belcher, 2004b. Three-dimensional Hydrogeologic Framework Model. Chapter E of Death Valley Regional Groundwater Flow System, Nevada and California - Hydrogeologic Framework and Transient Groundwater Flow Model. U.S. Geological Survey Scientific Investigations Report 2004-5205. Pp. 165-255.

Faunt, C.C, J.B. Blainey, M.C. Hill, F.A. D’Agnese, and G.M. O’Brian, 2004c. Transient Numerical Model. Chapter F of Death Valley Regional Groundwater Flow System, Nevada and California - Hydrogeologic Framework and Transient Groundwater Flow Model. U.S. Geological Survey Scientific Investigations Report 2004-5205. Pp. 256-352.

Halford, K.J. and R.T. Hanson, 2002. User guide for the drawdown-limited, multi-node well (MNW) package for the U.S. Geological Survey's modular three-dimensional finitedifference ground-water flow model, versions MODFLOW-96 and MODFLOW-2000: U.S. Geological Survey Open-File Report 02-293, 33 p.

Harbaugh, A.W., E.R. Banta, M.C. Hill, and M.G. McDonald, 2000. MODFLOW-2000, the U.S. Geological Survey modular ground-water model -- User guide to modularization concepts and the groundwater flow process: U.S. Geological Survey Open-File Report 00-92, $121 \mathrm{p}$. 
Hill, M.C., E.R. Banta, A.W. Harbaugh, and E.R. Anderman, 2000. MODFLOW-2000, the U.S. Geological Survey modular groundwater model -- User guide to the observation, sensitivity, and parameter-estimation processes and three post-processing programs: U.S. Geological Survey Open-File Report 00-184, 210 p.

IT Corporation, 1996. Underground test area subproject, Phase I, Data analysis task, Volume VI. Groundwater flow model data documentation package: Las Vegas, Nevada. Report ITLV/10972-81 prepared for the U.S. Department of Energy.

Pollock, D.W., 1994. User's Guide for MODPATH/MODPATH-PLOT, Version 3: A particle tracking post-processing package for MODFLOW, the U.S. Geological Survey finitedifference ground-water flow model: U.S. Geological Survey Open-File Report 94-464, $6 \mathrm{ch}$.

San Juan, C.A., W.R. Belcher, R.J. Laczniak, and H.M. Putnum, 2004. Hydrologic Components for Model Development. Chapter C of Death Valley Regional Groundwater Flow System, Nevada and California - Hydrogeologic Framework and Transient Groundwater Flow Model. U.S. Geological Survey Scientific Investigations Report 20045205. Pp. 99-136.

Sweetkind, D.S., W.R. Belcher, C.C. Faunt, and C.J. Potter, 2004. Geology and Hydrogeology. Chapter B of Death Valley Regional Groundwater Flow System, Nevada and California - Hydrogeologic Framework and Transient Groundwater Flow Model. U.S. Geological Survey Scientific Investigations Report 2004-5205. Pp. 21-98. 


\section{DISTRIBUTION}

Ron Baugh

Bechtel Nevada

P.O. Box 98521

Las Vegas, NV 89193-8521

Erwin Faqua, Contracting Officer

Acquisition and Financial Assistance

Department

Office of Business Services

NNSA Albuquerque Office

P.O. Box 5400

Albuquerque, NM 87185-5400

Dave Finnegan

Los Alamos National Laboratory

C-INC, M/S J514

Los Alamos, NM 87945

Ed Forness

Stockpile Stewardship Division

Nevada Site Office

National Nuclear Security Administration

U.S. Department of Energy

P.O. Box 98518

Las Vegas, NV 89193-8518

David Hudson

Bechtel Nevada

P.O. Box 98521, M/S NTS273

Las Vegas, NV 89193-8521

Bruce Hurley

Hydrology Program Manager

Environment, Safety and Health Division

Nevada Site Office

National Nuclear Security Administration

U.S. Department of Energy

P.O. Box 98518

Las Vegas, NV 89193-8518
Kenneth Hoar, Director

Environment, Safety and Health Division

Nevada Site Office

National Nuclear Security Administration

U.S. Department of Energy

P.O. Box 98518

Las Vegas, NV 89193-8518

Marjory Jones

Division of Hydrologic Sciences

Desert Research Institute

2215 Raggio Parkway

Reno, NV 89512-1095

Annie Kersting

Lawrence Livermore National Laboratory

Isotope Sciences Division

L-213

P.O. Box 808

Livermore, CA 94550

Randy Laczniak

Water Resources Division

U.S. Geological Survey

160 N. Stephanie St.

Henderson, NV 89074-8829

Peter Sanders

Environmental Restoration Division

Nevada Site Office

National Nuclear Security Administration

U.S. Department of Energy

P.O. Box 98518

Las Vegas, NV 89193-8518

David Shafer

Division of Hydrologic Sciences

Desert Research Institute

755 E. Flamingo Road

Las Vegas, NV 89119-7363 
Bonnie Thompson

U.S. Geological Survey

160 N. Stephanie Street

Henderson, NV 89074

Don Van Etten

Environmental Technical Services

Bechtel Nevada

Bldg. 652/ Nevada Test Site

Mercury, NV 89023

Bill Wilborn

Environmental Restoration Division

Nevada Site Office

National Nuclear Security Administration

U.S. Department of Energy

P.O. Box 98518

Las Vegas, NV 89193-8518

Nevada State Library and Archives

State Publications

100 North Stewart Street

Carson City, NV 89701-4285

Archives

Getchell Library

University of Nevada, Reno

DeLaMare Library/262

University of Nevada, Reno

Document Section, Library

University of Nevada, Las Vegas

4505 Maryland Parkway

Las Vegas, NV 89154

Library

Stoller-Navarro Joint Venture

7710 W. Cheyenne, Bldg. 3

Las Vegas, NV 89128
Library

Southern Nevada Science Center

Desert Research Institute

755 E. Flaming Road

Las Vegas, NV 89119-7363

Public Reading Facility

c/o Nuclear Testing Archive

Nevada Site Office

National Nuclear Security Administration

U.S. Department of Energy

P.O. Box 98521, M/S 400

Las Vegas, NV 89193-8521

Technical Library

Nevada Site Office

National Nuclear Security Administration

U.S. Department of Energy

P.O. Box 98518

Las Vegas, NV 89193-8518

Office of Scientific and Technical

Information

U.S. Department of Energy

P.O. Box 62

Oak Ridge, TN 37831-9939

(electronic copy) 